\title{
Central Circadian Clock Regulates Energy Metabolism
}

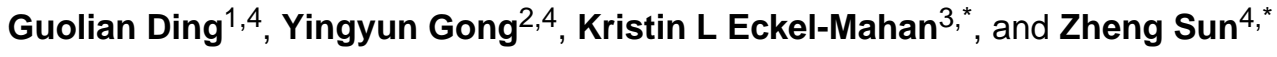 \\ ${ }^{1}$ International Peace Maternity and Child Health Hospital, School of Medicine, Shanghai Jiao \\ Tong University, Shanghai 200030, China \\ ${ }^{2}$ Department of Endocrinology and Metabolism, the First Affiliated Hospital of Nanjing Medical \\ University, Nanjing 210029, China \\ ${ }^{3}$ Institute of Molecular Medicine, McGovern Medical School, University of Texas Health Science \\ Center at Houston, Houston, TX 77030, USA \\ ${ }^{4}$ Department of Medicine, Division of Endocrinology, Diabetes, and Metabolism; Department of \\ Molecular and Cellular Biology, Baylor College of Medicine, Houston, TX 77030, USA
}

\begin{abstract}
Our body not only responds to environmental changes but also anticipates them. The light and dark cycle with the period of about 24 hours is a recurring environmental change that determines the diurnal variation in food availability and safety from predators in nature. As a result, the circadian clock is evolved in most animals to align locomotor behaviors and energy metabolism with the light cue. The central circadian clock in mammals is located at the suprachiasmatic nucleus (SCN) of the hypothalamus in the brain. We here review the molecular and anatomic architecture of the central circadian clock in mammals; describe the experimental and observational evidence that suggests a critical role of the central circadian clock in shaping systemic energy metabolism; and discuss the involvement of endocrine factors, neuropeptides, and the autonomic nervous system in the metabolic functions of the central circadian clock.
\end{abstract}

\section{Keywords}

Circadian clock; energy metabolism; SCN; hormone; autonomic nervous system

\section{Introduction}

Metabolic disorders, including obesity and type 2 diabetes, have reached pandemic levels in modern human societies. The underlying etiology was assumed to be an imbalance between total calorie intake and total energy expenditure. However, recent studies have suggested that the temporal pattern of calorie intake plays a critical in the pathogenesis of metabolic disorders. Restricting feeding exclusively to the active/dark phase almost eliminated high fat diet-induced metabolic disruption without changing total calorie intake in mice (Hatori et al., 2012; Tsai et al., 2013). Conversely, restricting feeding exclusively to the normal sleep phase disturbed metabolism in animals (Bray et al., 2010, 2013). In human, shiftwork has

\footnotetext{
*Correspondence: kristin.1.mahan@uth.tmc.edu and zheng.sun@bcm.edu.
} 
been associated with increased susceptibility to many metabolic disorders (Karlsson et al., 2001; Kubo et al., 2011; Suwazono et al., 2008). It has also been recognized that patients with cardiovascular diseases have a higher risk of heart attacks in the early morning compared to other times of the day (Takeda and Maemura, 2016) and that many diabetes patients display the dawn phenomenon, abnormal elevation of blood glucose in the early morning (Monnier et al., 2013). These findings not only demonstrate that time of the day is a critical factor in metabolism, but also pose a challenge to the homeostasis concept in physiology. Instead of homeostatic, many biological processes are actually homeodynamic.

The biological system is intrinsically rhythmic rather than trying to stay in a steady state. Robust rhythmic patterns, on a time scale ranging from milliseconds to months, are observed in many biological processes such as neuronal firing, heartbeat, breathing, sleeping, feeding, reproduction, molting, and migration, across a variety of animals in nature. Circadian rhythms, with a period of about 24 hours, is fundamental biological rhythms that are essential for normal energy metabolism. Most living animals sleep in a circadian pattern, with the body rotating between anabolism during the active/feeding phase and catabolism during the sleep/fasting phase.

The circadian rhythm is manifested at multiple levels. (1) At the whole-organism behavioral level, both consummatory behaviors and locomotor activities exhibit robust rhythm, which leads to diurnal patterns of calorie intake and energy expenditure. This behavioral rhythm is controlled by the central nervous system and is directly entrained by light that is perceived by the eye. (2) At the tissue and organ level, metabolic organs such as liver, muscle, and adipose receive or release different metabolites depending on the time of the day. The direction and the rate of metabolic fluxes within the metabolic organs are driven by two sets of mechanisms: anticipatory mechanism governed by the endogenous circadian clock within the metabolic tissue and responsive mechanisms that react to external neuronal, behavioral, or endocrine factors. (3) At the cellular and molecular level, many intracellular signaling pathways are involved. The anticipatory mechanism is controlled by the molecular clock machinery that, through various transcription factors and coregulators, orchestrates rhythmic gene expression of many metabolic enzymes. The responsive mechanisms, on the other hand, are initiated by binding of an external signaling molecule to its cellular receptor. For example, the insulin receptor at the cell membrane initiates cytosolic kinase cascades in response to elevated blood insulin levels during feeding, while the glucocorticoid receptor in the cell nucleus alters gene expression in response to oscillating glucocorticoid levels that are dictated by the central nervous system (Oster et al., 2017). We will review recent findings on these mechanisms, with an emphasis on how the central circadian clock controls systemic energy metabolism.

\section{Intrinsic rhythm of energy metabolism}

Glucose is a major fuel source for many cells and the body has developed intricate regulatory mechanisms to maintain normal blood glucose levels. Within the normal range, blood glucose levels exhibit a clear daily rhythm in healthy human subjects as well as in animals (Kalsbeek et al., 2014; La Fleur, 2003). The basal fasting glucose levels peak at the onset of locomotor activities during the transition from the sleep phase to the active phase 
(Cailotto et al., 2005; Challet et al., 2004; La Fleur et al., 1999). Interestingly, glucose tolerance also shows rhythm, with the highest glucose tolerance in the morning and the lowest tolerance at evening or night in human (Leung et al., 2017). In one study addressing rhythmicity in glucose tolerance, blood insulin and glucose levels were measured continuously for $24 \mathrm{~h}$ in normal healthy human subjects under a constant glucose infusion. Blood glucose levels display around 15\% elevation at around the middle of the sleep as compared to daytime levels in all subjects. The results are not confounded by the infusion rate or on the time elapsed since the beginning of the infusion because the timing of initiation of the infusion was varied to differentiate effects of the circadian time from effects of the infusion duration (Van Cauter et al., 1989).

Insulin is the major hormone controlling blood glucose levels. Both secretion of insulin from the pancreas and the systemic insulin sensitivity display circadian rhythm (Kitazawa, 2013). In one study addressing rhythmicity of insulin throughout the circadian cycle, rats were subjected to a feeding regimen of six identical meals equally distributed over a $24 \mathrm{~h}$ period in order to remove the entraining capacity of food (Kalsbeek A., 1998). Under these conditions, basal blood glucose levels peak at the onset of the active phase while basal insulin levels peak at the late sleep phase. Food-induced increase in blood glucose levels is almost identical across different times. Food-induced increase in insulin levels is the most dramatic during the early active phase and clearly diminished during the second half of the sleep phase (Kalsbeek A., 1998). These results show that the circadian regulation of basal blood glucose and feeding-induced insulin responses is independent of the feeding schedule.

Insulin lowers blood glucose levels by suppressing endogenous glucose production (EGP) from the liver and promoting glucose rate of disposition (Rd) through uptake by the muscle and adipose tissues. The glucose tolerance reaches the highest point of the day at the activity onset. This diurnal variation in glucose tolerance is unlikely to be caused by variations in insulin secretion because glucose-induced insulin secretion is almost identical across different time points in rats (la Fleur et al., 2001a). This suggests that the circadian rhythm of insulin sensitivity underlies the diurnal variation in glucose tolerance. Hyperinsulinemic euglycemic clamp analysis, the gold standard assay for systemic insulin sensitivity, has been performed at different times of the day. Zeitgeber time (ZT) is used to indicate the time of the day during the normal $12 \mathrm{~h}$ light/12h dark cycles with ZT0 indicating the onset of light and ZT12 indicating the onset of darkness. Clamp analysis of mice showed that the glucose infusion rate (GIR) at ZT18 is higher than ZT6 in mice. This is mainly contributed by lower EGP under the hyperinsulinemic condition at ZT18 than ZT6 because blood glucose Rd does not show changes between ZT6 and ZT18 (Coomans et al., 2013a). Consistent with this study, a separate study found that fasting glucose at ZT7 is higher than that at ZT1, ZT13, or ZT19 in mice, while GIR at ZT7 is lower than GIR at ZT1, ZT13, or ZT19 (Shi et al., 2013). Glucose Rd change is minimal, with a slightly higher Rd at ZT14 than ZT2 in rats. However, in another study, mice displayed higher glucose tolerance at ZT11 than ZT1 (Arble et al., 2015). 


\section{The molecular circadian clock}

At the molecular level, what gives rise to the circadian rhythm is a cell-autonomous transcription-translation feedback loop that exists in most cells of the body (Takahashi, 2017). The core molecular clock is composed of multiple transcription factors with short half-lives. In mammals, CLOCK and BMAL1 (brain and muscle ARNT-like 1) forms a heterodimeric complex and transcriptionally activates the expression of Cryptochromes (CRYs), Periods (PERs), and REV-ERBs (nuclear receptor subfamily 1, group D, member 1 and 2) (Figure 1) (Albrecht et al., 1997; Balsalobre et al., 1998; Bunger et al., 2000; Gekakis et al., 1998; Kume et al., 1999; Shearman et al., 1997, 2000; Shigeyoshi et al., 1997; Sun et al., 1997; Tei et al., 1997; Vitaterna et al., 1994). Once the PERs and CRYs proteins have reached a critical concentration, they directly bind to the CLOCK/BMAL1 complex and block their transactivation activities. REV-ERBs, on the other hand, bind to the BMAL1 promoter and transcriptionally suppress BMAL1 gene expression (Preitner et al., 2002). Once the CLOCK/BMAL1 activity is suppressed, CRYs, PERs, and REV-ERBs themselves start to decay because their own gene expression is shut down. Once the decay induces the protein levels to drop below a certain threshold, their inhibition on CLOCK/BMAL1 is disarmed, allowing CLOCK/BMAL1 to be reactivated. Such negative feedback regulation forms a self-sustainable cycle that repeats itself every $24 \mathrm{~h}$. These genes described above are referred to as core clock genes because they are required for the molecular clock to generate circadian rhythm. Depletion of these genes and their paralogs renders the clock nonfunctional and causes loss of intrinsic behavioral circadian rhythm in the absence of external light cues (Takahashi, 2017).

Most of the central circadian clock genes in mammals exist as paralogs including PER1/2/3, CRY1/2, and REV-ERBa/ $\beta$. The transcription factor NPAS2 (neuronal PAS domain protein 2 ) is able to functionally substitute for CLOCK in the central clock in mice to regulate circadian rhythmicity, suggesting that CLOCK and NPAS2 can independently heterodimerize with BMAL1 to maintain molecular and behavioral rhythmicity (DeBruyne et al., 2007). Generally, all paralog genes need to be knocked out to confer arrhythmicity under constant darkness. The only exception is BMAL1, whose single knockout confers arrhythmicity, despite the presence of its paralog BMAL2 (Bunger et al., 2000). BMAL1 knockout mice also display hypoinsulinemia and glucose intolerance as well as abnormal locomotor activities and feeding behaviors (Marcheva et al., 2010). Interestingly, constitutive expression of BMAL2 rescued the behavioral and metabolic phenotypes of BMAL1 knockout mice (Shi et al., 2010). It was postulated that BMAL2 is regulated by BMAL1 and that BMAL1 knockout actually results in dysfunction of both BMAL1 and BMAL2 (Shi et al., 2010). REV-ERBa/ $\beta$ belong to the nuclear receptor superfamily of ligand-regulated transcription factors (Dumas et al., 1994; Lazar et al., 1989; Miyajima et al., 1989). REV$\mathrm{ERBa} / \beta$ compete with RORa $/ \beta / \gamma$ (retinoic acid-related orphan receptors) for DNA binding (Preitner et al., 2002; Sato et al., 2004), which further regulates other rhythmic transcription factors including NFIL3 (nuclear factor, interleukin-3 regulated; also known as E4BP4), DBP (D-box binding protein), TEF (thyrotroph embryonic factor), and HLF (hepatic leukaemia factor) (Gachon et al., 2004; Mitsui et al., 2001). 
The phase, period, and amplitude for the oscillation of the core clock genes are subject to modulation by multiple environmental factors. This allows the molecular clock to be aligned with the environment, a process referred to as entrainment. Many signaling molecules can respond to environmental cues and regulate the activity or stability of the proteins encoded by the core clock genes. Currently known regulators include casein kinase 1 (CK1) (Lee et al., 2001), phosphoprotein phosphatase (Lee et al., 2011), FBXL3 (an F-box-type E3 ligase) (Busino et al., 2007; Godinho et al., 2007; Siepka et al., 2007), FBXW7 (another F-box protein E3 ligase) (Zhao et al., 2016), O-GlcNAc transferase (OGT) (Kaasik et al., 2013), sirtuins (Asher et al., 2008; Nakahata et al., 2008), and AMP-activated protein kinases (AMPK) (Um et al., 2007; Lamia et al., 2009).

In addition to the upstream cytosolic signaling pathways, a number of chromatin remodelers and epigenome modifiers work closely with the core clock machinery and serve as output mechanisms for the clock to regulate gene expression (Mendoza-Viveros et al., 2017). The CLOCK/BMAL1 complex directly associates with various histone acetyltransferases, including p300, CREB-binding protein (CBP) and p300/CBP-associated factor (PCAF), to promote histone acetylation and transcription activation (Curtis et al., 2004; Etchegaray et al., 2003). CLOCK also has histone acetyltransferase activity by itself (Doi et al., 2006). CLOCK/BMAL1 also recruits histone methyltransferases and demethylases, such as mixed lineage leukemia 1 (MLL1) and Jumonji/ARID domain-containing protein 1A (JARID1a), which contributes to rhythmic histone methylation (DiTacchio et al., 2011; Katada and Sassone-Corsi, 2010). CRY proteins can recruit enhancer of zeste homolog 2 (EZH2), a histone methyltransferase of the polycomb repressive complex 2 (PRC2), that contributes to transcriptional repression (Etchegaray et al., 2006). PER proteins can recruit histone deacetylase 1 (HDAC1) and methyltransferase such as SUV39h (Duong and Weitz, 2014). REV-ERBs can recruit nuclear receptor corepressors (NCORs) and HDAC3 that regulates expression of many metabolic enzymes in the liver and muscles (Feng et al., 2011; Hong et al., 2017; Sun et al., 2013; Yin and Lazar, 2005).

\section{Neural anatomy of the central circadian clock}

Although the molecular clock machinery operates in almost all cells throughout the body, the master circadian clock that dictates the behavioral rhythm is within the brain. The suprachiasmatic nucleus ( $\mathrm{SCN}$ ) of the hypothalamus is the site of the central circadian clock in mammals. Bilateral SCN lesions cause locomotor arrhythmicity under even the normal light/dark cycle (Ibuka et al., 1977). Grafting of the SCN into arrhythmic animals restores normal circadian rhythmicity that exhibited the period of the donor genotype (Lehman et al., 1987; Ralph et al., 1990), demonstrating that the SCN is the bona fide location of the central clock. Interestingly, grafting SCN even within a semipermeable polymeric capsule is able to restore locomotor rhythm, suggesting that diffusive factors contribute to $\mathrm{SCN}$-originated signals during the control of locomotor rhythm (Silver et al., 1996). The SCN is a paired structure with a ventral core region receiving photic input and a dorsal shell region receiving non-photic input. Most SCN neurons are positive with $\gamma$-aminobutyric acid (GABA). The core region is enriched with neurons expressing vasoactive intestinal polypeptide (VIP) and the shell region is enriched with neurons expressing arginine vasopressin (AVP) (Welsh et al., 2010). The core region projects to the shell region as well as the lateral 
subparaventricular zone (SPZ) while the shell region projects to the dorsomedial hypothalamus (DMH) and medial SPZ (Leak et al., 1999) (Figure 2).

The SCN receives many afferent neural connections (Morin, 2013). The best-characterized one originates from the retina and targets the SCN with a distinct projection of the optic nerve known as the retinohypothalamic tract (RHT). This projection allows photic information, received by rod or cone photoreceptors or intrinsically photoreceptive retinal ganglion cells (ipRGCs), gains access to the central clock (Lucas et al., 2012; Pickard, 1982). This photic information influences phase and period of the central circadian clock, a process referred to as photoentrainment. SCN in both diurnal and nocturnal is the same for the astronomical times (Challet, 2007; Dardente et al., 2004). It is therefore believed that the downstream polysynaptic relay mediates the activity difference between diurnal and nocturnal animals (Smale et al., 2003). Actually, some animal species can switch between diurnal and nocturnal behaviors (Hut et al., 2012).

Another robust afferent projections to the $\mathrm{SCN}$ is the geniculohypothalamic tract (GHT) from the thalamic intergeniculate leaflet (IGL) and ventral lateral geniculate nucleus (vLGN), regions that receive projections from retinal ipRGCs (Mikkelsen, 1992; Moore et al., 2000). It has been postulated that the GHT mediates non-photic arousal-inducing phase shifts of circadian rhythms (Harrington, 1997). Recently, it was shown that optogenetic activation of GHT neurons suppresses SCN responses to retinal input in a time-dependent manner, suggesting that the GHT allows the thalamic activity to gate retinal input to the SCN according to the time of day (Hanna et al., 2017). A third well known afferent projection to the $\mathrm{SCN}$ is serotonergic neurons originating from the median raphe (MnR). Disruption of this input causes an earlier onset and later offset of the active phase as well as increased SCN sensitivity to photoentrainment, which demonstrates a critical role of the MnR in modulating the light sensitivity of the SCN central clock (Mistlberger et al., 2000; Morin, 1999). Pharmacological blockade of the serotonin signaling within the SCN renders mice unable to be synchronized by wheel running without changing the overall locomotor activity, suggesting that the serotonin afferents are required for physical activity-mediated entrainment of the SCN central clock (Edgar et al., 1997).

The SCN receives projections from the dorsomedial hypothalamus (DMH), an input that plays a role in food anticipatory activities (FAA). When nocturnal animals anticipate the scheduled food in the light cycle when they would otherwise normally sleep, the DMH neuronal activities increased and inhibited the SCN neuronal activity through the GABAergic inhibitory input into the SCN. DMH lesions diminished FAA while double lesions of the DMH and SCN restored FAA. These findings suggest that DMH-mediated inhibition of the SCN activity overrides clock-controlled sleep and permits locomotor activity in the sleep phase (Acosta-Galvan et al., 2011). In addition to the projections described above, the SCN has been found to be directly innervated by over 35 anatomical routes (Morin, 2013), which allows the central clock to integrate multiple signals received from different brain regions.

The SCN neurons send efferent projections to multiple regions of the brain. The two subdivisions of the SCN project to different hypothalamic areas, with the core projecting to 
the lateral SPZ and the shell to the DMH and the medial SPZ (Leak and Moore, 2001; Leak et al., 1999). The SPZ of the hypothalamus is the main efferent target of neural projections from the SCN and an important relay for the circadian timing system. The ventral SPZ (vSPZ) is critical for rhythms of sleep and locomotor activity. Interestingly, anterograde tracing with biotinylated dextran amine (BDA) showed that the anatomic architecture from the SCN to the VSPZ are highly conserved between diurnal Nile grass rats and nocturnal lab rats despite distinct oscillation phases of the vSPZ neuronal activities, suggesting that the neural basis for a diurnal or nocturnal phase preference is independent of the anatomic structures (Schwartz et al., 2011). Unlike the vSPZ, the dorsal SPZ (dSPZ) relays signals from the SCN in controlling body temperature rhythms (Lu et al., 2001).

The SCN projects to the paraventricular nucleus (PVN) of the hypothalamus, which dictates the circadian rhythm of circulating glucocorticoids. Anterograde tracing revealed a direct connection between the SCN and the PVN neurons producing corticotropin-releasing hormones (CRH) (Vrang et al., 1995). AVP released from the SCN during the light cycle represses CRH releases in the PVN in nocturnal animals. In diurnal animals, AVP stimulates CRH releases, suggesting a neurochemical difference in the PVN interneurons between different chronotypes (Oster et al., 2017). In addition to the direct projection to the PVN, diffusive endocrine effects of the AVP, indirect multi-synaptic projections from the SCN to the PVN, as well as neuronal routes connecting the SCN with the adrenal cortex could all play important roles in the glucocorticoid rhythm (Buijs et al., 1998).

The SCN also projects to the arcuate nucleus (ARC), a hypothalamic region that controls feeding and energy expenditure. A robust circadian rhythm was observed in the firing activity of the ARC neurons expressing a-melanocyte-stimulating hormone (a-MSH), with the peak activity in the late dark cycle in rats. Bilateral SCN lesions blocked this rhythm and a direct projection from the SCN to the ARC was identified by neuronal tracing (GuzmánRuiz et al., 2014). This finding suggested a potential time-dependent regulation of the appetite by the central circadian clock. The ARC also projects to the SCN. Surgical microcuts that eliminate these reciprocal connections lead to arrhythmicity in locomotor activities, corticosterone levels, and body temperature in the constant darkness condition in rats. Interestingly, the SCN clock gene rhythmicity was not altered by these micro-cuts while the ARC gene rhythmicity was disrupted (Buijs et al., 2017). These findings suggest that the autonomous clock in the SCN controls the molecular clock in the ARC and potentially other brain regions through a complex neuronal projection network.

Although neurons have been considered as the major pacemaker for the central clock, astrocytes also contribute to circadian rhythms. All the core clock genes are expressed in astrocytes. Depletion of either BMAL1 or CK1 $1 \varepsilon$ specifically in the SCN astrocytes increased the period of both the SCN molecular clock rhythm and the locomotor behavioral rhythm (Tso et al., 2017). Pharmacological modulation of a GABA receptor rescued the behavioral phenotype, suggesting the involvement of the GABA signaling (Barca-Mayo et al., 2017). In contrast to the SCN neurons, SCN astrocytes are more active at night as measured by intracellular calcium imaging. The SCN astrocytes suppress SCN neuronal activity by regulating extracellular glutamate levels that are sensed by a pre-synaptic glutamate receptor complex in the SCN neurons (Brancaccio et al., 2017). 


\section{Evidence supporting a role of central clock in energy metabolism}

\section{Lesion}

The SCN lesion caused arrhythmicity in sleep and wake behaviors, consummatory behaviors, and energy expenditure (Meyer-Bernstein et al., 1999; Coomans et al., 2013b; Malloy et al., 2012). The SCN lesion also abolished daily change in plasma free fatty acids, disrupted the circadian rhythm in glucose tolerance, and blocked hyperglycemic effects of GABA-A antagonist at the PVN (Kalsbeek et al., 2008a). Bilateral SCN lesion dramatically reduced GIR and increased EGP without changing glucose Rd (Coomans et al., 2013b). Transplant of the fetal SCN into the $3^{\text {rd }}$ ventricle of the SCN-lesioned animals, reinstated locomotor rhythm, although did not restore the rhythm of glucocorticoids or melatonin (Lehman et al., 1987; LeSauter et al., 1997; Silver et al., 1996). Parabiosis between the SCN-lesioned and SCN-intact mice showed that circulating factors or behavioral cues are sufficient to maintain the clock gene expression rhythms in liver and kidney, but not in heart, spleen, or skeletal muscle, indicating that the central clock communicates with different peripheral tissues through distinct mechanisms (Guo et al., 2005). Bilateral SCN lesion eliminated circadian rhythms of blood glucose and insulin, and abolished time-dependent responses to 2-deoxy-D-glucose, an inhibitor of glucose utilization (Nagai et al., 1994). The SCN-lesioned rats did not show the glucose rhythm even on a scheduled feeding regimen (La Fleur et al., 1999). The rhythm of glucose tolerance was also lost in SCN-lesioned rats (la Fleur et al., 2001a).

\section{Light and feeding}

Nighttime light, shift work, and social jetlag have become prevalent since industrialization, which could disrupt our central circadian clock and contribute to the pandemic of metabolic disorders (Fonken and Nelson, 2014; Roenneberg and Merrow, 2016). Shift workers who work from $10 \mathrm{pm}$ to 6 am make up about $20 \%$ of working force in modern society (Antunes et al., 2010) and have a higher prevalence of obesity and heart disease (Karlsson et al., 2001; Kubo et al., 2011; Suwazono et al., 2008). Dim light at night or prolonged daily light exposure promotes obesity and metabolic disorders in animal models (Aubrecht et al., 2015; Kooijman et al., 2015; Opperhuizen et al., 2015). Housing mice under constant light caused arrhythmicity in locomotor activity, increased food intake, reduced energy expenditure, increased body fat mass, and impaired insulin sensitivity (Coomans et al., 2013a; Shi et al., 2013). Although blood glucose displays robust diurnal changes in constant darkness in rats, light exposure at any circadian time could increase blood glucose, suggesting that light can directly regulate blood glucose independently of the circadian clock (Challet et al., 2004).

In addition to light, feeding is an important factor that entrains the peripheral circadian clocks in metabolic tissues. On one hand, feeding is not required for rhythmic glucose or insulin responses in the normal physiological condition because a regimen of 6 identical meals per day did not disrupt rhythmic glucose or insulin responses (Kalsbeek A., 1998). On the other hand, food can cause profound remodeling of the molecular clock in metabolic tissues (Eckel-Mahan et al., 2013; Tognini et al., 2017). Scheduled feeding in particular can reverse the changes in the amplitude or phase of the peripheral clocks that were altered by the constant light housing in mice (Hamaguchi et al., 2015). Restricting feeding only within 
the active phase almost eliminated high fat diet-induced metabolic disruption without changing total calorie intake in mice (Hatori et al., 2012; Tsai et al., 2013). Conversely, restricting feeding in the normal sleep phase disturbed metabolism in animals (Bray et al., 2010, 2013; Yasumoto et al., 2016). These studies suggest that the feeding schedule and the light schedule need to be aligned with each other to maintain metabolic health. Night-eating syndrome (NES) is characterized by a delayed circadian pattern of food intake and is defined by consumption of $25 \%$ or more of the total daily calories after the evening meal (Allison et al., 2010). With disrupted rhythmic patterns of sleep and eating, NES is strongly associated with metabolic disorders, with a particularly high prevalence among individuals seeking gastric bypass surgery (Gallant et al., 2012; O’Reardon et al., 2004).

\section{Sleep disturbance}

Circadian clock disruption is intertwined with sleep disturbance (Tsuneki et al., 2016). Human epidemiology studies have found that lack of sufficient sleep or poor sleep quality is associated with diabetes, metabolic disorders, increased appetite, obesity, and disrupted hormone levels (Koren et al., 2016). In addition to the observational studies, experiments have also been performed in human subjects. Restricting sleep to $5 \mathrm{~h}$ per day for 5 days caused $\sim 20 \%$ reduction in oral and intravenous insulin sensitivity in normal healthy human subjects (Eckel et al., 2015). In another human study, restricting sleep to 4 h per day for 5 days reduced systemic insulin sensitivity by $25 \%$, which was mostly due to non-hepatic insulin resistance and was associated with increased fasting nonesterified fatty acids (NEFA) levels in the blood (Rao et al., 2015). Actually, loss of one-night sleep was sufficient to cause glucose intolerance in human (Cedernaes et al., 2016). Elevated sympathetic tone, glucocorticoids levels, and growth hormone levels could all contribute to the sleep restriction-induced metabolic disruption.

\section{Neurectomy and pharmaceuticals}

The SCN innervates both the sympathetic and parasympathetic nervous systems (SNS and PSNS) (Bartness et al., 2001; Buijs and Kalsbeek, 2001). Virus-mediated neuronal tracing revealed that the SCN innervated the liver via both the SNS and PSNS. Administration of GABA-A or VAP antagonists at the PVN elevated blood glucose levels in rats, which was blocked by hepatic sympathectomy, but not hepatic parasympathectomy. Silencing neuronal firing by tetrodotoxin administration at the SCN, but not the PVN, elevated blood glucose levels (Kalsbeek et al., 2004). Consistent with this finding, tetrodotoxin administration at the SCN, but not at the PVN, increased EGP in the glucose clamp analysis (Foppen et al., 2016). Considering the direct projection from the SCN to the PVN and the high basal blood glucose levels in anti-phase with the SCN neuronal firing activity in rats, these findings support a role of the SCN-PVN-SNS-EGP signaling in governing the rhythmic blood glucose levels under the normal physiological condition. Interestingly, hepatic sympathectomy in combination with a non-circadian feeding regimen disrupted the blood glucose rhythmicity without disrupting the clock gene expression rhythmicity in the liver, suggesting the molecular clock in the liver is not sufficient for generating the blood glucose rhythmicity (Cailotto et al., 2005). Of note, simultaneous hepatic sympathectomy and parasympathectomy in combination with a non-circadian feeding regimen did not abolish 
the blood glucose rhythmicity, suggesting that unbalanced interplay between the SNS and PSNS accounts for the elevated glucose levels (Cailotto et al., 2008).

In addition to the liver, the SCN also innervates white adipose tissues (WAT) and brown adipose tissues (BAT) through sympathetic nerves as shown by retrograde tracing from adipose tissues (Bartness et al., 2001). BAT is a major thermogenetic tissue critical for maintaining the body temperature that has a clear circadian rhythm culminating in the dark cycle in nocturnal animals. The thermoregulatory median preoptic nucleus (MnPO) is innervated by both VAP-expressing SCN neurons and a-MSH-expressing ARC neurons. Administration of AVP into the MnPO decreased body temperature in the dark phase, while an AVP receptor antagonist increased body temperature in the early light cycle. Conversely, administration of a melanocortin receptor agonist into the MnPO prevented the diurnal drop in body temperature, while a melanocortin receptor antagonist induced a nocturnal decrease in body temperature. These findings suggest that the opposite effects of VAP and a-MSH govern the body temperature rhythm through the MnPO (Guzmán-Ruiz et al., 2015). The ventromedial hypothalamus (VMH) is another brain region that controls BAT activity and body temperature. VMH-specific depletion of BMAL1 in mice increased nocturnal expression of thermogenic genes in the BAT, enhanced BAT lipid oxidation, and increased body temperature especially in the dark cycle, without affecting the clock gene oscillation in the BAT. Administration of a $\beta 3$ adrenoreceptor antagonist rescued the phenotype, demonstrating a role of the SNS in relaying the circadian signals into the BAT (Orozco-Solis et al., 2016).

\section{Genetic animal models}

Knock-out or mutation knock-in of core clock genes in mice altered glucose or lipid metabolism, which has been summarized recently (Eckel-Mahan and Sassone-Corsi, 2013). Genetic deletion of core clock genes, including CLOCK, BMAL1, PERs, CRYs, REVERBs, or RORs led to several metabolic abnormalities and disrupted glucose homeostasis. In addition to the core clock genes, genetic manipulation of clock-controlled output mediators could specifically affect metabolism without altering the clock itself or other clockcontrolled biological processes, which has therapeutic implications. REV-ERBs recruit the NCOR/HDAC3 complex to the chromatin on a genome-wide scale in a rhythmic manner in the liver and skeletal muscles, regulating the diurnal metabolic fluxes in lipid anabolism in the liver and amino acid catabolism in the muscle. Depletion of HDAC3 in the liver or muscle disrupted the rhythmic metabolic flexibility and caused unique metabolic disorders (Feng et al., 2011; Sun et al., 2012, 2011; Hong et al., 2017). In addition to the molecular output mediators, the SNS is an important anatomic mediator that connects the central clock with metabolic processes in the liver, BAT, and other peripheral tissues through adrenergic receptors in the target tissue (Yi et al., 2010; Zhang and Bi, 2015). Recent studies have demonstrated diverse metabolic functions of adrenergic receptors using genetic mouse models (Table 1).

\section{Human genetics}

Smith-Magenis syndrome (SMS) is a rare genetic disorder characterized by intellectual disability, sleep disturbance, obesity, metabolic changes, multiple congenital anomalies, and 
psychiatric behaviors. It is caused by a heterozygous microdeletion on chromosome region $17 \mathrm{p} 11.2$ containing the retinoic acid-induced 1 (RAI1) gene or mutations within RAI1. RAI1 is a transcription factor and was shown to regulate expression of CLOCK as well as other circadian clock genes. Dysregulation of the molecular clock is therefore considered as an underlying cause of many abnormalities in SMS patients (Chen et al., 2015).

Genetic association studies have identified the association of BMAL1 polymorphism with hypertension ( $\mathrm{P}=0.0042$ for rs9633835) and diabetes $(\mathrm{P}=0.0036$ for rs7947951) (Diabetes Genetics Initiative of Broad Institute of Harvard and MIT, Lund University, and Novartis Institutes of BioMedical Research et al., 2007; Scott et al., 2007; Woon et al., 2007). A series of CLOCK polymorphisms have also been associated with susceptibility to nonalcoholic fatty liver disease, metabolic syndrome ( $\mathrm{P}=0.0015$ for $\mathrm{rs} 1801260)$, overweight ( $\mathrm{P}<0.001$ for combined $\mathrm{rs} 1554483 \mathrm{G}$ and rs4864548A), or small dense lowdensity lipoprotein levels in the circulation (Sookoian et al., 2007; Scott et al., 2008; Sookoian et al., 2008; Tsuzaki et al., 2010). A recent GWAS has identified a missense polymorphism (rs10462020; Gly639Val) of PER3 associated with type 2 diabetes (Below et al., 2011). Another meta-analysis of multiple GWAS studies identified CRY2 associated with fasting glucose levels (Dupuis et al., 2010). Genetic variants in the gene melatonin receptor 1B (MTNR1B) have been consistently shown to have a robust association with diabetes, although how it contributes to diabetes pathophysiology remains unclear (BouatiaNaji et al., 2009; Lyssenko et al., 2009; Prokopenko et al., 2009; Bonnefond and Froguel, 2017).

\section{Hormones and neuropeptides in metabolic functions of the central clock}

Hormones play pivotal roles in metabolic homeostasis. A common feature for many hormones is the robust circadian rhythm that is not only due to responsiveness to environmental or behavioral variations associated with the sleep/wake cycle but also is regulated by the anticipatory circadian clock under the normal physiological condition (Gamble et al., 2014). When the normal circadian rhythm is disrupted by irregular light or feeding schedules, the endocrine system is also altered and can contribute to the metabolic derangement in these conditions (Bedrosian et al., 2016). Neuropeptides and neurotransmitters are involved at all levels of the SCN clock functions, including receiving the upstream input from environmental entraining cues, synchronizing different neurons within the SCN, and relaying the SCN efferent information to other parts of the body (An et al., 2013; Reghunandanan and Reghunandanan, 2006). Understanding how hormones and neuropeptides contribute to the clock function is important for successful manipulation of the clock with therapeutic implications.

Melatonin is released from the pineal gland and is unique in that it peaks in the dark phase in both diurnal and nocturnal animals, while other hormones display the opposite circadian phase between nocturnal and diurnal animals. Melatonin release is controlled by the SCN. GABA release from the SCN inhibits the PVN-originated projections to the pineal gland during the light cycle. This rhythmic GABAergic inhibitory signal, in combination with a 
constant glutamatergic excitatory projection from the $\mathrm{SCN}$, restricts the melatonin release from the pineal gland only during the dark cycle (Kalsbeek and Fliers, 2013). Suppression of melatonin secretion by pinealectomy abolished the blood glucose circadian rhythm in rats under a non-circadian scheduled feeding regimen without altering blood insulin levels (la Fleur et al., 2001b). Pinealectomy impaired glucose tolerance, which could be corrected by exogenous melatonin administration (Forrestel et al., 2017). The chronic melatonin administration was shown to improve insulin sensitivity and ameliorate obesity in some animal models (Agil et al., 2013; Nduhirabandi et al., 2011), but was also shown to cause glucose intolerance in other studies (Cagnacci et al., 2001; Rubio-Sastre et al., 2014). Many inbred mouse strains including the C57BL/6J mice have no detectable levels of melatonin due to genetic mutations (Kasahara et al., 2010; Roseboom et al., 1998). However, the depletion of melatonin receptor type 1 or type 2 in mice abolished the blood glucose circadian rhythm without altering the rhythmic expression of clock genes in the skeletal muscle, liver, or adipose tissue (Owino et al., 2016).

Glucocorticoid is another class of hormones with robust circadian rhythm and pivotal roles in energy metabolism. The blood glucocorticoid level peaks at the activity onset, which is regulated by the hypothalamic-pituitary-adrenal (HPA) axis. The corticotrophin-releasing hormone (CRH) from the PVN stimulates adrenocorticotropic hormone (ACTH) from the pituitary (Kalsbeek and Fliers, 2013). The SCN rhythmically releases vasopressin during the light in rats, which inhibits CRH neurons in the PVN. This control could be through diffusive vasopressin via the cerebrospinal fluid (CSF) or through the SCN to PVN neural projections (Vrang et al., 1995). PVN neurons in nocturnal animals respond to vasopressin differently from diurnal animals (Kalsbeek et al., 2008b). Glucocorticoid can partially restore the peripheral circadian rhythm due to the SCN lesion, suggesting that it could relay signals from the SCN to peripheral tissues (Reddy et al., 2007; Pezük et al., 2012). Within the target tissue, glucocorticoid binds to the glucocorticoid receptor and regulates glucose utilization as well as hepatic gluconeogenesis (Oster et al., 2017).

Orexin is a neuropeptide secreted by the lateral hypothalamus (LH) with low levels in the CSF during sleep and high levels during wake (Chieffi et al., 2017). Darkness activates orexin neurons in nocturnal rodents (Marston et al., 2008), while orexin suppresses the SCN neurons either directly or indirectly through augmenting the IGL-mediated suppression of the SCN neurons (Belle et al., 2014; Palus et al., 2015). Activation of the orexin at the onset of the active phase not only facilitates wakefulness but also adapts the peripheral glucose metabolism to the active phase (Kalsbeek and Fliers, 2013). Orexin deficiency caused sleep disorders, obesity, and glucose intolerance in human and mouse models (Chemelli et al., 1999; Hara et al., 2005; Lin et al., 1999; Tsuneki et al., 2008). Overexpression of orexin protected mice from diet-induced obesity and glucose intolerance, mainly through the orexin receptor 2 (OX2R). Pharmacological activation of the LH neurons or orexin ICV administration increased EGP in rats, an effect that can be blocked by orexin receptor 1 (OX1R) antagonist or hepatic sympathectomy (Yi et al., 2009). Although ICV administration of orexin during the day increased blood glucose levels in mice, orexin administration at night decreased blood glucose levels associated with reduced gluconeogenesis gene expression, an effect that can be blocked by hepatic parasympathectomy (Tsuneki et al., 2015). Thus, orexin bidirectionally regulates hepatic 
gluconeogenesis through an OX2R-sympathetic pathway in the day and an OX1Rparasympathetic pathway at night.

Acetylcholine is a major neurotransmitter of the PSNS through activation of muscarinic acetylcholine receptors (mAChRs) in target tissues. The subtype M3 is the only mAChR expressed in the mouse hepatocytes. Interestingly, knockout of the mAChR-M3 did not alter glucose tolerance or hepatic expression of metabolic enzymes in mice fed either normal chow or high-fat diet, suggesting that metabolic effects mediated by hepatic vagal nerves are acetylcholine independent (Li et al., 2009).

\section{Concluding remarks}

Energy metabolism is a biological process with intrinsic circadian rhythms at multiple levels, which is orchestrated by both the anticipatory mechanism from the central circadian clock and the responsive mechanism that reacts to the sleep/wake cycle or fasting/feeding cycle. The molecular clock is composed of a handful of transcription factors in negative feedback loops that exist in the brain as well as in the peripheral tissues. The central clock in the SCN of the hypothalamus is entrained by light and synchronizes with oscillators in other brain regions through neuronal projections or neuropeptides. The central clock regulates systemic metabolism through the autonomous nervous systems and endocrine factors. Disruption of the circadian clock system by irregular light or feeding schedules contributes to metabolic disorders such as obesity and diabetes. Harnessing the circadian clock system with chronotherapy or lifestyle intervention is a promising strategy combating against these metabolic diseases.

\section{Acknowledgments}

We apologize to colleagues whose work we failed to include due to an oversight on our part. The work in our laboratories is supported by National Institute of Health (DK111436, ES027544, and CA215591) and American Heart Association (30970064).

\section{References}

Acosta-Galvan G, Yi C-X, van der Vliet J, Jhamandas JH, Panula P, Angeles-Castellanos M, Del Carmen Basualdo M, Escobar C, and Buijs RM (2011). Interaction between hypothalamic dorsomedial nucleus and the suprachiasmatic nucleus determines intensity of food anticipatory behavior. Proc. Natl. Acad. Sci. U. S. A 108, 5813-5818. [PubMed: 21402951]

Agil A, Reiter RJ, Jiménez-Aranda A, Ibán-Arias R, Navarro-Alarcón M, Marchal JA, Adem A, and Fernández-Vázquez G (2013). Melatonin ameliorates low-grade inflammation and oxidative stress in young Zucker diabetic fatty rats. J. Pineal Res 54, 381-388. [PubMed: 23020082]

Albrecht U, Sun ZS, Eichele G, and Lee CC (1997). A differential response of two putative mammalian circadian regulators, mper1 and mper2, to light. Cell 91, 1055-1064. [PubMed: 9428527]

Allison KC, Lundgren JD, O'Reardon JP, Geliebter A, Gluck ME, Vinai P, Mitchell JE, Schenck CH, Howell MJ, Crow SJ, et al. (2010). Proposed diagnostic criteria for night eating syndrome. Int. J. Eat. Disord 43, 241-247. [PubMed: 19378289]

An S, Harang R, Meeker K, Granados-Fuentes D, Tsai CA, Mazuski C, Kim J, Doyle FJ, Petzold LR, and Herzog ED (2013). A neuropeptide speeds circadian entrainment by reducing intercellular synchrony. Proc. Natl. Acad. Sci. U. S. A 110, E4355-4361. [PubMed: 24167276] 
Antunes LC, Levandovski R, Dantas G, Caumo W, and Hidalgo MP (2010). Obesity and shift work: chronobiological aspects. Nutr. Res. Rev 23, 155-168. [PubMed: 20122305]

Arble DM, Holland J, Ottaway N, Sorrell J, Pressler JW, Morano R, Woods SC, Seeley RJ, Herman JP, Sandoval DA, et al. (2015). The melanocortin-4 receptor integrates circadian light cues and metabolism. Endocrinology 156, 1685-1691. [PubMed: 25730108]

Asensio C, Jimenez M, Kühne F, Rohner-Jeanrenaud F, and Muzzin P (2005). The lack of betaadrenoceptors results in enhanced insulin sensitivity in mice exhibiting increased adiposity and glucose intolerance. Diabetes 54, 3490-3495. [PubMed: 16306366]

Asher G, Gatfield D, Stratmann M, Reinke H, Dibner C, Kreppel F, Mostoslavsky R, Alt FW, and Schibler U (2008). SIRT1 regulates circadian clock gene expression through PER2 deacetylation. Cell 134, 317-328. [PubMed: 18662546]

Aubrecht TG, Jenkins R, and Nelson RJ (2015). Dim light at night increases body mass of female mice. Chronobiol. Int 32, 557-560. [PubMed: 25431079]

Balsalobre A, Damiola F, and Schibler U (1998). A serum shock induces circadian gene expression in mammalian tissue culture cells. Cell 93, 929-937. [PubMed: 9635423]

Barca-Mayo O, Pons-Espinal M, Follert P, Armirotti A, Berdondini L, and De Pietri Tonelli D (2017). Astrocyte deletion of Bmal1 alters daily locomotor activity and cognitive functions via GABA signalling. Nat. Commun 8, 14336. [PubMed: 28186121]

Bartness TJ, Song CK, and Demas GE (2001). SCN efferents to peripheral tissues: implications for biological rhythms. J. Biol. Rhythms 16, 196-204. [PubMed: 11407779]

Bedrosian TA, Fonken LK, and Nelson RJ (2016). Endocrine Effects of Circadian Disruption. Annu. Rev. Physiol 78, 109-131. [PubMed: 26208951]

Belle MDC, Hughes ATL, Bechtold DA, Cunningham P, Pierucci M, Burdakov D, and Piggins HD (2014). Acute suppressive and long-term phase modulation actions of orexin on the mammalian circadian clock. J. Neurosci. Off. J. Soc. Neurosci 34, 3607-3621.

Below JE, Gamazon ER, Morrison JV, Konkashbaev A, Pluzhnikov A, McKeigue PM, Parra EJ, Elbein SC, Hallman DM, Nicolae DL, et al. (2011). Genome-wide association and meta-analysis in populations from Starr County, Texas, and Mexico City identify type 2 diabetes susceptibility loci and enrichment for expression quantitative trait loci in top signals. Diabetologia 54, 20472055. [PubMed: 21647700]

Bonnefond A, and Froguel P (2017). Disentangling the Role of Melatonin and its Receptor MTNR1B in Type 2 Diabetes: Still a Long Way to Go? Curr. Diab. Rep 17, 122. [PubMed: 29063374]

Bouatia-Naji N, Bonnefond A, Cavalcanti-Proença C, Sparsø T, Holmkvist J, Marchand M, Delplanque J, Lobbens S, Rocheleau G, Durand E, et al. (2009). A variant near MTNR1B is associated with increased fasting plasma glucose levels and type 2 diabetes risk. Nat. Genet 41 , 89-94. [PubMed: 19060909]

Brancaccio M, Patton AP, Chesham JE, Maywood ES, and Hastings MH (2017). Astrocytes Control Circadian Timekeeping in the Suprachiasmatic Nucleus via Glutamatergic Signaling. Neuron 93, 1420-1435.e5. [PubMed: 28285822]

Bray MS, Tsai J-Y, Villegas-Montoya C, Boland BB, Blasier Z, Egbejimi O, Kueht M, and Young ME (2010). Time-of-day-dependent dietary fat consumption influences multiple cardiometabolic syndrome parameters in mice. Int. J. Obes 2005 34, 1589-1598.

Bray MS, Ratcliffe WF, Grenett MH, Brewer RA, Gamble KL, and Young ME (2013). Quantitative analysis of light-phase restricted feeding reveals metabolic dyssynchrony in mice. Int. J. Obes 2005 37, 843-852.

Buijs RM, and Kalsbeek A (2001). Hypothalamic integration of central and peripheral clocks. Nat. Rev. Neurosci 2, 521-526. [PubMed: 11433377]

Buijs FN, Guzmán-Ruiz M, León-Mercado L, Basualdo MC, Escobar C, Kalsbeek A, and Buijs RM (2017). Suprachiasmatic Nucleus Interaction with the Arcuate Nucleus; Essential for Organizing Physiological Rhythms. ENeuro 4.

Buijs RM, Hermes MH, and Kalsbeek A (1998). The suprachiasmatic nucleus-paraventricular nucleus interactions: a bridge to the neuroendocrine and autonomic nervous system. Prog. Brain Res 119, 365-382. [PubMed: 10074800] 
Bunger MK, Wilsbacher LD, Moran SM, Clendenin C, Radcliffe LA, Hogenesch JB, Simon MC, Takahashi JS, and Bradfield CA (2000). Mop3 is an essential component of the master circadian pacemaker in mammals. Cell 103, 1009-1017. [PubMed: 11163178]

Burcelin R, Uldry M, Foretz M, Perrin C, Dacosta A, Nenniger-Tosato M, Seydoux J, Cotecchia S, and Thorens B (2004). Impaired glucose homeostasis in mice lacking the alpha1b-adrenergic receptor subtype. J. Biol. Chem 279, 1108-1115. [PubMed: 14581480]

Busino L, Bassermann F, Maiolica A, Lee C, Nolan PM, Godinho SIH, Draetta GF, and Pagano M (2007). SCFFbxl3 controls the oscillation of the circadian clock by directing the degradation of cryptochrome proteins. Science 316, 900-904. [PubMed: 17463251]

Cagnacci A, Arangino S, Renzi A, Paoletti AM, Melis GB, Cagnacci P, and Volpe A (2001). Influence of melatonin administration on glucose tolerance and insulin sensitivity of postmenopausal women. Clin. Endocrinol. (Oxf.) 54, 339-346. [PubMed: 11298086]

Cailotto C, La Fleur SE, Van Heijningen C, Wortel J, Kalsbeek A, Feenstra M, Pévet P, and Buijs RM (2005). The suprachiasmatic nucleus controls the daily variation of plasma glucose via the autonomic output to the liver: are the clock genes involved? Eur. J. Neurosci 22, 2531-2540. [PubMed: 16307595]

Cailotto C, van Heijningen C, van der Vliet J, van der Plasse G, Habold C, Kalsbeek A, Pévet P, and Buijs RM (2008). Daily rhythms in metabolic liver enzymes and plasma glucose require a balance in the autonomic output to the liver. Endocrinology 149, 1914-1925. [PubMed: 18162516]

Cedernaes J, Lampola L, Axelsson EK, Liethof L, Hassanzadeh S, Yeganeh A, Broman J-E, Schiöth $\mathrm{HB}$, and Benedict C (2016). A single night of partial sleep loss impairs fasting insulin sensitivity but does not affect cephalic phase insulin release in young men. J. Sleep Res 25, 5-10.

Challet E (2007). Minireview: Entrainment of the suprachiasmatic clockwork in diurnal and nocturnal mammals. Endocrinology 148, 5648-5655. [PubMed: 17901231]

Challet E, Malan A, Turek FW, and Van Reeth O (2004). Daily variations of blood glucose, acid-base state and PCO2 in rats: effect of light exposure. Neurosci. Lett 355, 131-135. [PubMed: 14729252]

Chemelli RM, Willie JT, Sinton CM, Elmquist JK, Scammell T, Lee C, Richardson JA, Williams SC, Xiong Y, Kisanuki Y, et al. (1999). Narcolepsy in orexin knockout mice: molecular genetics of sleep regulation. Cell 98, 437-451. [PubMed: 10481909]

Chen L, Mullegama SV, Alaimo JT, and Elsea SH (2015). Smith-Magenis syndrome and its circadian influence on development, behavior, and obesity - own experience. Dev. Period Med 19, 149-156. [PubMed: 26384114]

Chieffi S, Carotenuto M, Monda V, Valenzano A, Villano I, Precenzano F, Tafuri D, Salerno M, Filippi N, Nuccio F, et al. (2017). Orexin System: The Key for a Healthy Life. Front. Physiol 8, 357. [PubMed: 28620314]

Coomans CP, van den Berg SAA, Houben T, van Klinken J-B, van den Berg R, Pronk ACM, Havekes LM, Romijn JA, van Dijk KW, Biermasz NR, et al. (2013a). Detrimental effects of constant light exposure and high-fat diet on circadian energy metabolism and insulin sensitivity. FASEB J. Off. Publ. Fed. Am. Soc. Exp. Biol 27, 1721-1732.

Coomans CP, van den Berg SAA, Lucassen EA, Houben T, Pronk ACM, van der Spek RD, Kalsbeek A, Biermasz NR, Willems van Dijk K, Romijn JA, et al. (2013b). The suprachiasmatic nucleus controls circadian energy metabolism and hepatic insulin sensitivity. Diabetes 62, 1102-1108. [PubMed: 23274903]

Curtis AM, Seo S, Westgate EJ, Rudic RD, Smyth EM, Chakravarti D, FitzGerald GA, and McNamara $\mathrm{P}$ (2004). Histone acetyltransferase-dependent chromatin remodeling and the vascular clock. J. Biol. Chem 279, 7091-7097. [PubMed: 14645221]

Dardente H, Menet JS, Challet E, Tournier BB, Pévet P, and Masson-Pévet M (2004). Daily and circadian expression of neuropeptides in the suprachiasmatic nuclei of nocturnal and diurnal rodents. Brain Res. Mol. Brain Res 124, 143-151. [PubMed: 15135222]

DeBruyne JP, Weaver DR, and Reppert SM (2007). CLOCK and NPAS2 have overlapping roles in the suprachiasmatic circadian clock. Nat. Neurosci 10, 543-545. [PubMed: 17417633]

Diabetes Genetics Initiative of Broad Institute of Harvard and MIT, Lund University, and Novartis Institutes of BioMedical Research, Saxena R, Voight BF, Lyssenko V, Burtt NP, de Bakker PIW, 
Chen H, Roix JJ, Kathiresan S, Hirschhorn JN, et al. (2007). Genome-wide association analysis identifies loci for type 2 diabetes and triglyceride levels. Science 316, 1331-1336. [PubMed: 17463246]

DiTacchio L, Le HD, Vollmers C, Hatori M, Witcher M, Secombe J, and Panda S (2011). Histone lysine demethylase JARID1a activates CLOCK-BMAL1 and influences the circadian clock. Science 333, 1881-1885. [PubMed: 21960634]

Doi M, Hirayama J, and Sassone-Corsi P (2006). Circadian regulator CLOCK is a histone acetyltransferase. Cell 125, 497-508. [PubMed: 16678094]

Dumas B, Harding HP, Choi HS, Lehmann KA, Chung M, Lazar MA, and Moore DD (1994). A new orphan member of the nuclear hormone receptor superfamily closely related to Rev-Erb. Mol. Endocrinol. Baltim. Md 8, 996-1005.

Duong HA, and Weitz CJ (2014). Temporal orchestration of repressive chromatin modifiers by circadian clock Period complexes. Nat. Struct. Mol. Biol 21, 126-132. [PubMed: 24413057]

Dupuis J, Langenberg C, Prokopenko I, Saxena R, Soranzo N, Jackson AU, Wheeler E, Glazer NL, Bouatia-Naji N, Gloyn AL, et al. (2010). New genetic loci implicated in fasting glucose homeostasis and their impact on type 2 diabetes risk. Nat. Genet 42, 105-116. [PubMed: 20081858]

Eckel RH, Depner CM, Perreault L, Markwald RR, Smith MR, McHill AW, Higgins J, Melanson EL, and Wright KP (2015). Morning Circadian Misalignment during Short Sleep Duration Impacts Insulin Sensitivity. Curr. Biol. CB 25, 3004-3010. [PubMed: 26549253]

Eckel-Mahan K, and Sassone-Corsi P (2013). Metabolism and the circadian clock converge. Physiol. Rev 93, 107-135. [PubMed: 23303907]

Eckel-Mahan KL, Patel VR, de Mateo S, Orozco-Solis R, Ceglia NJ, Sahar S, Dilag-Penilla SA, Dyar KA, Baldi P, and Sassone-Corsi P (2013). Reprogramming of the circadian clock by nutritional challenge. Cell 155, 1464-1478. [PubMed: 24360271]

Edgar DM, Reid MS, and Dement WC (1997). Serotonergic afferents mediate activity-dependent entrainment of the mouse circadian clock. Am. J. Physiol 273, R265-269. [PubMed: 9249559]

Etchegaray J-P, Lee C, Wade PA, and Reppert SM (2003). Rhythmic histone acetylation underlies transcription in the mammalian circadian clock. Nature 421, 177-182. [PubMed: 12483227]

Etchegaray J-P, Yang X, DeBruyne JP, Peters AHFM, Weaver DR, Jenuwein T, and Reppert SM (2006). The polycomb group protein EZH2 is required for mammalian circadian clock function. J. Biol. Chem 281, 21209-21215. [PubMed: 16717091]

Fagerholm V, Grönroos T, Marjamäki P, Viljanen T, Scheinin M, and Haaparanta M (2004). Altered glucose homeostasis in alpha2A-adrenoceptor knockout mice. Eur. J. Pharmacol 505, 243-252. [PubMed: 15556159]

Feng D, Liu T, Sun Z, Bugge A, Mullican SE, Alenghat T, Liu XS, and Lazar MA (2011). A circadian rhythm orchestrated by histone deacetylase 3 controls hepatic lipid metabolism. Science 331, 1315-1319. [PubMed: 21393543]

Fernandes GW, Ueta CB, Fonseca TL, Gouveia CHA, Lancellotti CL, Brum PC, Christoffolete MA, Bianco AC, and Ribeiro MO (2014). Inactivation of the adrenergic receptor $\beta 2$ disrupts glucose homeostasis in mice. J. Endocrinol 221, 381-390. [PubMed: 24868110]

la Fleur SE, Kalsbeek A, Wortel J, Fekkes ML, and Buijs RM (2001a). A daily rhythm in glucose tolerance: a role for the suprachiasmatic nucleus. Diabetes 50, 1237-1243. [PubMed: 11375322]

la Fleur SE, Kalsbeek A, Wortel J, van der Vliet J, and Buijs RM (2001b). Role for the pineal and melatonin in glucose homeostasis: pinealectomy increases night-time glucose concentrations. J. Neuroendocrinol 13, 1025-1032. [PubMed: 11722698]

Fonken L, and Nelson R (2014). The effects of light at night on circadian clocks and metabolism. PubMed - NCBI

Foppen E, Tan A. a. T., Ackermans MT, Fliers E, and Kalsbeek A (2016). Suprachiasmatic Nucleus Neuropeptides and Their Control of Endogenous Glucose Production. J. Neuroendocrinol 28.

Forrestel AC, Miedlich SU, Yurcheshen M, Wittlin SD, and Sellix MT (2017). Chronomedicine and type 2 diabetes: shining some light on melatonin. Diabetologia 60, 808-822. [PubMed: 27981356] 
Gachon F, Fonjallaz P, Damiola F, Gos P, Kodama T, Zakany J, Duboule D, Petit B, Tafti M, and Schibler U (2004). The loss of circadian PAR bZip transcription factors results in epilepsy. Genes Dev 18, 1397-1412. [PubMed: 15175240]

Gallant AR, Lundgren J, and Drapeau V (2012). The night-eating syndrome and obesity. Obes. Rev. Off. J. Int. Assoc. Study Obes 13, 528-536.

Gamble KL, Berry R, Frank SJ, and Young ME (2014). Circadian clock control of endocrine factors. Nat. Rev. Endocrinol 10, 466-475. [PubMed: 24863387]

Gekakis N, Staknis D, Nguyen HB, Davis FC, Wilsbacher LD, King DP, Takahashi JS, and Weitz CJ (1998). Role of the CLOCK protein in the mammalian circadian mechanism. Science 280, 15641569. [PubMed: 9616112]

Godinho SIH, Maywood ES, Shaw L, Tucci V, Barnard AR, Busino L, Pagano M, Kendall R, Quwailid MM, Romero MR, et al. (2007). The after-hours mutant reveals a role for Fbxl3 in determining mammalian circadian period. Science 316, 897-900. [PubMed: 17463252]

Guo H, Brewer JM, Champhekar A, Harris RBS, and Bittman EL (2005). Differential control of peripheral circadian rhythms by suprachiasmatic-dependent neural signals. Proc. Natl. Acad. Sci. U. S. A 102, 3111-3116. [PubMed: 15710878]

Guzmán-Ruiz M, Saderi N, Cazarez-Márquez F, Guerrero-Vargas NN, Basualdo MC, Acosta-Galván G, and Buijs RM (2014). The suprachiasmatic nucleus changes the daily activity of the arcuate nucleus a-MSH neurons in male rats. Endocrinology 155, 525-535. [PubMed: 24265453]

Guzmán-Ruiz MA, Ramirez-Corona A, Guerrero-Vargas NN, Sabath E, Ramirez-Plascencia OD, Fuentes-Romero R, León-Mercado LA, Basualdo Sigales M, Escobar C, and Buijs RM (2015). Role of the Suprachiasmatic and Arcuate Nuclei in Diurnal Temperature Regulation in the Rat. J. Neurosci. Off. J. Soc. Neurosci 35, 15419-15429.

Hamaguchi Y, Tahara Y, Hitosugi M, and Shibata S (2015). Impairment of Circadian Rhythms in Peripheral Clocks by Constant Light Is Partially Reversed by Scheduled Feeding or Exercise. J. Biol. Rhythms 30, 533-542. [PubMed: 26467286]

Hanna L, Walmsley L, Pienaar A, Howarth M, and Brown TM (2017). Geniculohypothalamic GABAergic projections gate suprachiasmatic nucleus responses to retinal input. J. Physiol 595, 3621-3649. [PubMed: 28217893]

Hara J, Yanagisawa M, and Sakurai T (2005). Difference in obesity phenotype between orexinknockout mice and orexin neuron-deficient mice with same genetic background and environmental conditions. Neurosci. Lett 380, 239-242. [PubMed: 15862893]

Harrington ME (1997). The ventral lateral geniculate nucleus and the intergeniculate leaflet: interrelated structures in the visual and circadian systems. Neurosci. Biobehav. Rev 21, 705-727. [PubMed: 9353800]

Hatori M, Vollmers C, Zarrinpar A, DiTacchio L, Bushong EA, Gill S, Leblanc M, Chaix A, Joens M, Fitzpatrick JAJ, et al. (2012). Time-restricted feeding without reducing caloric intake prevents metabolic diseases in mice fed a high-fat diet. Cell Metab 15, 848-860. [PubMed: 22608008]

Hong S, Zhou W, Fang B, Lu W, Loro E, Damle M, Ding G, Jager J, Zhang S, Zhang Y, et al. (2017). Dissociation of muscle insulin sensitivity from exercise endurance in mice by HDAC3 depletion. Nat. Med 23, 223-234. [PubMed: 27991918]

Hut RA, Kronfeld-Schor N, van der Vinne V, and De la Iglesia H (2012). In search of a temporal niche: environmental factors. Prog. Brain Res 199, 281-304. [PubMed: 22877672]

Ibuka N, Inouye SI, and Kawamura H (1977). Analysis of sleep-wakefulness rhythms in male rats after suprachiasmatic nucleus lesions and ocular enucleation. Brain Res 122, 33-47. [PubMed: 837222]

Kaasik K, Kivimäe S, Allen JJ, Chalkley RJ, Huang Y, Baer K, Kissel H, Burlingame AL, Shokat KM, Ptáček LJ, et al. (2013). Glucose sensor O-GlcNAcylation coordinates with phosphorylation to regulate circadian clock. Cell Metab 17, 291-302. [PubMed: 23395175]

Kalsbeek A, and Fliers E (2013). Daily regulation of hormone profiles. Handb. Exp. Pharmacol 185226. [PubMed: 23604480]

Kalsbeek A, La Fleur S, Van Heijningen C, and Buijs RM (2004). Suprachiasmatic GABAergic inputs to the paraventricular nucleus control plasma glucose concentrations in the rat via sympathetic innervation of the liver. J. Neurosci. Off. J. Soc. Neurosci 24, 7604-7613. 
Kalsbeek A, Foppen E, Schalij I, Van Heijningen C, van der Vliet J, Fliers E, and Buijs RM (2008a). Circadian control of the daily plasma glucose rhythm: an interplay of GABA and glutamate. PloS One 3, e3194. [PubMed: 18791643]

Kalsbeek A, Verhagen LAW, Schalij I, Foppen E, Saboureau M, Bothorel B, Buijs RM, and Pévet P (2008b). Opposite actions of hypothalamic vasopressin on circadian corticosterone rhythm in nocturnal versus diurnal species. Eur. J. Neurosci 27, 818-827. [PubMed: 18279365]

Kalsbeek A, la Fleur S, and Fliers E (2014). Circadian control of glucose metabolism. Mol. Metab 3, 372-383. [PubMed: 24944897]

Kalsbeek A, S.J. (1998). Circadian control of insulin secretion is independent of the temporal distribution of feeding. - PubMed - NCBI

Karlsson B, Knutsson A, and Lindahl B (2001). Is there an association between shift work and having a metabolic syndrome? Results from a population based study of 27,485 people. Occup. Environ. Med 58, 747-752. [PubMed: 11600731]

Kasahara T, Abe K, Mekada K, Yoshiki A, and Kato T (2010). Genetic variation of melatonin productivity in laboratory mice under domestication. Proc. Natl. Acad. Sci. U. S. A 107, 6412 6417. [PubMed: 20308563]

Katada S, and Sassone-Corsi P (2010). The histone methyltransferase MLL1 permits the oscillation of circadian gene expression. Nat. Struct. Mol. Biol 17, 1414-1421. [PubMed: 21113167]

Kitazawa M (2013). Circadian rhythms, metabolism, and insulin sensitivity: transcriptional networks in animal models. Curr. Diab. Rep 13, 223-228. [PubMed: 23266563]

Kooijman S, van den Berg R, Ramkisoensing A, Boon MR, Kuipers EN, Loef M, Zonneveld TCM, Lucassen EA, Sips HCM, Chatzispyrou IA, et al. (2015). Prolonged daily light exposure increases body fat mass through attenuation of brown adipose tissue activity. Proc. Natl. Acad. Sci. U. S. A 112, 6748-6753. [PubMed: 25964318]

Koren D, Dumin M, and Gozal D (2016). Role of sleep quality in the metabolic syndrome. Diabetes Metab. Syndr. Obes. Targets Ther 9, 281-310.

Kubo T, Oyama I, Nakamura T, Shirane K, Otsuka H, Kunimoto M, Kadowaki K, Maruyama T, Otomo H, Fujino Y, et al. (2011). Retrospective cohort study of the risk of obesity among shift workers: findings from the Industry-based Shift Workers' Health study, Japan. Occup. Environ. Med 68, 327-331. [PubMed: 20884794]

Kume K, Zylka MJ, Sriram S, Shearman LP, Weaver DR, Jin X, Maywood ES, Hastings MH, and Reppert SM (1999). mCRY1 and mCRY2 are essential components of the negative limb of the circadian clock feedback loop. Cell 98, 193-205. [PubMed: 10428031]

La Fleur SE (2003). Daily rhythms in glucose metabolism: suprachiasmatic nucleus output to peripheral tissue. J. Neuroendocrinol 15, 315-322. [PubMed: 12588521]

La Fleur SE, Kalsbeek A, Wortel J, and Buijs RM (1999). A suprachiasmatic nucleus generated rhythm in basal glucose concentrations. J. Neuroendocrinol 11, 643-652. [PubMed: 10447803]

Lamia KA, Sachdeva UM, DiTacchio L, Williams EC, Alvarez JG, Egan DF, Vasquez DS, Juguilon H, Panda S, Shaw RJ, et al. (2009). AMPK regulates the circadian clock by cryptochrome phosphorylation and degradation. Science 326, 437-440. [PubMed: 19833968]

Lazar MA, Hodin RA, and Chin WW (1989). Human carboxyl-terminal variant of alpha-type c-erbA inhibits trans-activation by thyroid hormone receptors without binding thyroid hormone. Proc. Natl. Acad. Sci. U. S. A 86, 7771-7774. [PubMed: 2554288]

Leak RK, and Moore RY (2001). Topographic organization of suprachiasmatic nucleus projection neurons. J. Comp. Neurol 433, 312-334. [PubMed: 11298358]

Leak RK, Card JP, and Moore RY (1999). Suprachiasmatic pacemaker organization analyzed by viral transynaptic transport. Brain Res 819, 23-32. [PubMed: 10082857]

Lee H, Chen R, Kim H, Etchegaray J-P, Weaver DR, and Lee C (2011). The period of the circadian oscillator is primarily determined by the balance between casein kinase 1 and protein phosphatase 1. Proc. Natl. Acad. Sci. U. S. A 108, 16451-16456. [PubMed: 21930935]

Lehman MN, Silver R, Gladstone WR, Kahn RM, Gibson M, and Bittman EL (1987). Circadian rhythmicity restored by neural transplant. Immunocytochemical characterization of the graft and its integration with the host brain. J. Neurosci. Off. J. Soc. Neurosci 7, 1626-1638. 
LeSauter J, Romero P, Cascio M, and Silver R (1997). Attachment site of grafted SCN influences precision of restored circadian rhythm. J. Biol. Rhythms 12, 327-338. [PubMed: 9438881]

Leung GKW, Huggins CE, and Bonham MP (2017). Effect of meal timing on postprandial glucose responses to a low glycemic index meal: A crossover trial in healthy volunteers. Clin. Nutr. Edinb. Scotl

Li JH, Gautam D, Han S-J, Guettier J-M, Cui Y, Lu H, Deng C, O’Hare J, Jou W, Gavrilova O, et al. (2009). Hepatic muscarinic acetylcholine receptors are not critically involved in maintaining glucose homeostasis in mice. Diabetes 58, 2776-2787. [PubMed: 19752163]

Lin L, Faraco J, Li R, Kadotani H, Rogers W, Lin X, Qiu X, de Jong PJ, Nishino S, and Mignot E (1999). The sleep disorder canine narcolepsy is caused by a mutation in the hypocretin (orexin) receptor 2 gene. Cell 98, 365-376. [PubMed: 10458611]

Lu J, Zhang YH, Chou TC, Gaus SE, Elmquist JK, Shiromani P, and Saper CB (2001). Contrasting effects of ibotenate lesions of the paraventricular nucleus and subparaventricular zone on sleepwake cycle and temperature regulation. J. Neurosci. Off. J. Soc. Neurosci 21, 4864-4874.

Lucas RJ, Lall GS, Allen AE, and Brown TM (2012). How rod, cone, and melanopsin photoreceptors come together to enlighten the mammalian circadian clock. Prog. Brain Res 199, 1-18. [PubMed: 22877656]

Lyssenko V, Nagorny CLF, Erdos MR, Wierup N, Jonsson A, Spégel P, Bugliani M, Saxena R, Fex M, Pulizzi N, et al. (2009). Common variant in MTNR1B associated with increased risk of type 2 diabetes and impaired early insulin secretion. Nat. Genet 41, 82-88. [PubMed: 19060908]

Malloy JN, Paulose JK, Li Y, and Cassone VM (2012). Circadian rhythms of gastrointestinal function are regulated by both central and peripheral oscillators. Am. J. Physiol. Gastrointest. Liver Physiol 303, G461-473. [PubMed: 22723262]

Marcheva B, Ramsey KM, Buhr ED, Kobayashi Y, Su H, Ko CH, Ivanova G, Omura C, Mo S, Vitaterna MH, et al. (2010). Disruption of the clock components CLOCK and BMAL1 leads to hypoinsulinaemia and diabetes. Nature 466, 627-631. [PubMed: 20562852]

Marston OJ, Williams RH, Canal MM, Samuels RE, Upton N, and Piggins HD (2008). Circadian and dark-pulse activation of orexin/hypocretin neurons. Mol. Brain 1, 19. [PubMed: 19055781]

Mendoza-Viveros L, Bouchard-Cannon P, Hegazi S, Cheng AH, Pastore S, and Cheng H-YM (2017). Molecular modulators of the circadian clock: lessons from flies and mice. Cell. Mol. Life Sci. CMLS 74, 1035-1059. [PubMed: 27689221]

Meyer-Bernstein EL, Jetton AE, Matsumoto SI, Markuns JF, Lehman MN, and Bittman EL (1999). Effects of suprachiasmatic transplants on circadian rhythms of neuroendocrine function in golden hamsters. Endocrinology 140, 207-218. [PubMed: 9886827]

Mikkelsen JD (1992). The organization of the crossed geniculogeniculate pathway of the rat: a Phaseolus vulgaris-leucoagglutinin study. Neuroscience 48, 953-962. [PubMed: 1378578]

Mistlberger RE, Antle MC, Glass JD, and Miller JD (2000). Behavioral and Serotonergic Regulation of Circadian Rhythms. Biol. Rhythm Res 31, 240-283.

Mitsui S, Yamaguchi S, Matsuo T, Ishida Y, and Okamura H (2001). Antagonistic role of E4BP4 and PAR proteins in the circadian oscillatory mechanism. Genes Dev 15, 995-1006. [PubMed: 11316793]

Miyajima N, Horiuchi R, Shibuya Y, Fukushige S, Matsubara K, Toyoshima K, and Yamamoto T (1989). Two erbA homologs encoding proteins with different T3 binding capacities are transcribed from opposite DNA strands of the same genetic locus. Cell 57, 31-39. [PubMed: 2539258]

Monnier L, Colette C, Dejager S, and Owens D (2013). Magnitude of the dawn phenomenon and its impact on the overall glucose exposure in type 2 diabetes: is this of concern? Diabetes Care 36, 4057-4062. [PubMed: 24170753]

Moore RY, Weis R, and Moga MM (2000). Efferent projections of the intergeniculate leaflet and the ventral lateral geniculate nucleus in the rat. J. Comp. Neurol 420, 398-418. [PubMed: 10754510]

Morin LP (1999). Serotonin and the regulation of mammalian circadian rhythmicity. Ann. Med 31, 1233. [PubMed: 10219711]

Morin LP (2013). Neuroanatomy of the extended circadian rhythm system. Exp. Neurol 243, 4-20. [PubMed: 22766204] 
Nagai K, Nagai N, Sugahara K, Niijima A, and Nakagawa H (1994). Circadian rhythms and energy metabolism with special reference to the suprachiasmatic nucleus. Neurosci. Biobehav. Rev 18, 579-584. [PubMed: 7708372]

Nakahata Y, Kaluzova M, Grimaldi B, Sahar S, Hirayama J, Chen D, Guarente LP, and Sassone-Corsi P (2008). The NAD+-dependent deacetylase SIRT1 modulates CLOCK-mediated chromatin remodeling and circadian control. Cell 134, 329-340. [PubMed: 18662547]

Nduhirabandi F, Du Toit EF, Blackhurst D, Marais D, and Lochner A (2011). Chronic melatonin consumption prevents obesity-related metabolic abnormalities and protects the heart against myocardial ischemia and reperfusion injury in a prediabetic model of diet-induced obesity. $\mathrm{J}$. Pineal Res 50, 171-182. [PubMed: 21073520]

Opperhuizen A-L, van Kerkhof LWM, Proper KI, Rodenburg W, and Kalsbeek A (2015). Rodent models to study the metabolic effects of shiftwork in humans. Front. Pharmacol 6, 50. [PubMed: 25852554]

O'Reardon JP, Stunkard AJ, and Allison KC (2004). Clinical trial of sertraline in the treatment of night eating syndrome. Int. J. Eat. Disord 35, 16-26. [PubMed: 14705153]

Orozco-Solis R, Aguilar-Arnal L, Murakami M, Peruquetti R, Ramadori G, Coppari R, and SassoneCorsi P (2016). The Circadian Clock in the Ventromedial Hypothalamus Controls Cyclic Energy Expenditure. Cell Metab 23, 467-478. [PubMed: 26959185]

Oster H, Challet E, Ott V, Arvat E, de Kloet ER, Dijk D-J, Lightman S, Vgontzas A, and Van Cauter E (2017). The Functional and Clinical Significance of the 24-Hour Rhythm of Circulating Glucocorticoids. Endocr. Rev 38, 3-45. [PubMed: 27749086]

Owino S, Contreras-Alcantara S, Baba K, and Tosini G (2016). Melatonin Signaling Controls the Daily Rhythm in Blood Glucose Levels Independent of Peripheral Clocks. PloS One 11, e0148214. [PubMed: 26824606]

Palus K, Chrobok L, and Lewandowski MH (2015). Orexins/hypocretins modulate the activity of NPYpositive and -negative neurons in the rat intergeniculate leaflet via OX1 and OX2 receptors. Neuroscience 300, 370-380. [PubMed: 26022361]

Peterhoff M, Sieg A, Brede M, Chao C-M, Hein L, and Ullrich S (2003). Inhibition of insulin secretion via distinct signaling pathways in alpha2-adrenoceptor knockout mice. Eur. J. Endocrinol 149, 343-350. [PubMed: 14514350]

Pezük P, Mohawk JA, Wang LA, and Menaker M (2012). Glucocorticoids as entraining signals for peripheral circadian oscillators. Endocrinology 153, 4775-4783. [PubMed: 22893723]

Pickard GE (1982). The afferent connections of the suprachiasmatic nucleus of the golden hamster with emphasis on the retinohypothalamic projection. J. Comp. Neurol 211, 65-83. [PubMed: 7174884]

Preite NZ, Nascimento B.P.P. do, Muller CR, Américo ALV, Higa TS, Evangelista FS, Lancellotti CL, Henriques F. dos S., Batista ML, Bianco AC, et al. (2016). Disruption of beta3 adrenergic receptor increases susceptibility to DIO in mouse. J. Endocrinol 231, 259-269. [PubMed: 27672060]

Preitner N, Damiola F, Lopez-Molina L, Zakany J, Duboule D, Albrecht U, and Schibler U (2002). The orphan nuclear receptor REV-ERBalpha controls circadian transcription within the positive limb of the mammalian circadian oscillator. Cell 110, 251-260. [PubMed: 12150932]

Prokopenko I, Langenberg C, Florez JC, Saxena R, Soranzo N, Thorleifsson G, Loos RJF, Manning AK, Jackson AU, Aulchenko Y, et al. (2009). Variants in MTNR1B influence fasting glucose levels. Nat. Genet 41, 77-81. [PubMed: 19060907]

Ralph MR, Foster RG, Davis FC, and Menaker M (1990). Transplanted suprachiasmatic nucleus determines circadian period. Science 247, 975-978. [PubMed: 2305266]

Rao MN, Neylan TC, Grunfeld C, Mulligan K, Schambelan M, and Schwarz J-M (2015). Subchronic sleep restriction causes tissue-specific insulin resistance. J. Clin. Endocrinol. Metab 100, 16641671. [PubMed: 25658017]

Reddy AB, Maywood ES, Karp NA, King VM, Inoue Y, Gonzalez FJ, Lilley KS, Kyriacou CP, and Hastings MH (2007). Glucocorticoid signaling synchronizes the liver circadian transcriptome. Hepatol. Baltim. Md 45, 1478-1488. 
Reghunandanan V, and Reghunandanan R (2006). Neurotransmitters of the suprachiasmatic nuclei. J. Circadian Rhythms 4, 2. [PubMed: 16480518]

Roenneberg T, and Merrow M (2016). The Circadian Clock and Human Health. Curr. Biol. CB 26, R432-443. [PubMed: 27218855]

Roseboom PH, Namboodiri MA, Zimonjic DB, Popescu NC, Rodriguez IR, Gastel JA, and Klein DC (1998). Natural melatonin "knockdown" in C57BL/6J mice: rare mechanism truncates serotonin N-acetyltransferase. Brain Res. Mol. Brain Res 63, 189-197. [PubMed: 9838107]

Rubio-Sastre P, Scheer FAJL, Gómez-Abellán P, Madrid JA, and Garaulet M (2014). Acute melatonin administration in humans impairs glucose tolerance in both the morning and evening. Sleep 37, 1715-1719. [PubMed: 25197811]

Ruohonen ST, Ruohonen S, Gilsbach R, Savontaus E, Scheinin M, and Hein L (2012). Involvement of a2-adrenoceptor subtypes $\mathrm{A}$ and $\mathrm{C}$ in glucose homeostasis and adrenaline-induced hyperglycaemia. Neuroendocrinology 96, 51-59. [PubMed: 22327786]

Sato TK, Panda S, Miraglia LJ, Reyes TM, Rudic RD, McNamara P, Naik KA, FitzGerald GA, Kay SA, and Hogenesch JB (2004). A functional genomics strategy reveals Rora as a component of the mammalian circadian clock. Neuron 43, 527-537. [PubMed: 15312651]

Savontaus E, Fagerholm V, Rahkonen O, and Scheinin M (2008). Reduced blood glucose levels, increased insulin levels and improved glucose tolerance in alpha2A-adrenoceptor knockout mice. Eur. J. Pharmacol 578, 359-364. [PubMed: 17964569]

Schwartz MD, Urbanski HF, Nunez AA, and Smale L (2011). Projections of the suprachiasmatic nucleus and ventral subparaventricular zone in the Nile grass rat (Arvicanthis niloticus). Brain Res 1367, 146-161. [PubMed: 20971082]

Scott EM, Carter AM, and Grant PJ (2008). Association between polymorphisms in the Clock gene, obesity and the metabolic syndrome in man. Int. J. Obes 2005 32, 658-662.

Scott LJ, Mohlke KL, Bonnycastle LL, Willer CJ, Li Y, Duren WL, Erdos MR, Stringham HM, Chines PS, Jackson AU, et al. (2007). A genome-wide association study of type 2 diabetes in Finns detects multiple susceptibility variants. Science 316, 1341-1345. [PubMed: 17463248]

Shearman LP, Zylka MJ, Weaver DR, Kolakowski LF, and Reppert SM (1997). Two period homologs: circadian expression and photic regulation in the suprachiasmatic nuclei. Neuron 19, 1261-1269. [PubMed: 9427249]

Shearman LP, Sriram S, Weaver DR, Maywood ES, Chaves I, Zheng B, Kume K, Lee CC, van der Horst GT, Hastings MH, et al. (2000). Interacting molecular loops in the mammalian circadian clock. Science 288, 1013-1019. [PubMed: 10807566]

Shi S, Hida A, McGuinness OP, Wasserman DH, Yamazaki S, and Johnson CH (2010). Circadian clock gene Bmal1 is not essential; functional replacement with its paralog, Bmal2. Curr. Biol. CB 20, 316-321. [PubMed: 20153195]

Shi S, Ansari TS, McGuinness OP, Wasserman DH, and Johnson CH (2013). Circadian disruption leads to insulin resistance and obesity. Curr. Biol. CB 23, 372-381. [PubMed: 23434278]

Shi T, Papay RS, and Perez DM (2016a). a1A-Adrenergic receptor prevents cardiac ischemic damage through PKC6/GLUT1/4-mediated glucose uptake. J. Recept. Signal Transduct. Res 36, 261270. [PubMed: 26832303]

Shi Y, Shu Z-J, Xue X, Yeh C-K, Katz MS, and Kamat A (2016b). $\beta 2$-Adrenergic receptor ablation modulates hepatic lipid accumulation and glucose tolerance in aging mice. Exp. Gerontol 78, 3238. [PubMed: 26952573]

Shigeyoshi Y, Taguchi K, Yamamoto S, Takekida S, Yan L, Tei H, Moriya T, Shibata S, Loros JJ, Dunlap JC, et al. (1997). Light-induced resetting of a mammalian circadian clock is associated with rapid induction of the mPer1 transcript. Cell 91, 1043-1053. [PubMed: 9428526]

Siepka SM, Yoo S-H, Park J, Song W, Kumar V, Hu Y, Lee C, and Takahashi JS (2007). Circadian mutant Overtime reveals F-box protein FBXL3 regulation of cryptochrome and period gene expression. Cell 129, 1011-1023. [PubMed: 17462724]

Silver R, LeSauter J, Tresco PA, and Lehman MN (1996). A diffusible coupling signal from the transplanted suprachiasmatic nucleus controlling circadian locomotor rhythms. Nature 382, 810 813. [PubMed: 8752274] 
Smale L, Lee T, and Nunez AA (2003). Mammalian diurnality: some facts and gaps. J. Biol. Rhythms 18, 356-366. [PubMed: 14582852]

Sookoian S, Castaño G, Gemma C, Gianotti T-F, and Pirola C-J (2007). Common genetic variations in CLOCK transcription factor are associated with nonalcoholic fatty liver disease. World J. Gastroenterol. WJG 13, 4242-4248. [PubMed: 17696255]

Sookoian S, Gemma C, Gianotti TF, Burgueño A, Castaño G, and Pirola CJ (2008). Genetic variants of Clock transcription factor are associated with individual susceptibility to obesity. Am. J. Clin. Nutr 87, 1606-1615. [PubMed: 18541547]

Sun Z, Feng D, Everett LJ, Bugge A, and Lazar MA (2011). Circadian epigenomic remodeling and hepatic lipogenesis: lessons from HDAC3. Cold Spring Harb. Symp. Quant. Biol 76, 49-55. [PubMed: 21900149]

Sun Z, Miller RA, Patel RT, Chen J, Dhir R, Wang H, Zhang D, Graham MJ, Unterman TG, Shulman GI, et al. (2012). Hepatic Hdac3 promotes gluconeogenesis by repressing lipid synthesis and sequestration. Nat. Med 18, 934-942. [PubMed: 22561686]

Sun Z, Feng D, Fang B, Mullican SE, You S-H, Lim H-W, Everett LJ, Nabel CS, Li Y, Selvakumaran $\mathrm{V}$, et al. (2013). Deacetylase-independent function of HDAC3 in transcription and metabolism requires nuclear receptor corepressor. Mol. Cell 52, 769-782. [PubMed: 24268577]

Sun ZS, Albrecht U, Zhuchenko O, Bailey J, Eichele G, and Lee CC (1997). RIGUI, a putative mammalian ortholog of the Drosophila period gene. Cell 90, 1003-1011. [PubMed: 9323128]

Suwazono Y, Dochi M, Sakata K, Okubo Y, Oishi M, Tanaka K, Kobayashi E, and Nogawa K (2008). Shift work is a risk factor for increased blood pressure in Japanese men: a 14-year historical cohort study. Hypertens. Dallas Tex 1979 52, 581-586.

Takahashi JS (2017). Transcriptional architecture of the mammalian circadian clock. Nat. Rev. Genet 18, 164-179. [PubMed: 27990019]

Takeda N, and Maemura K (2016). Circadian clock and the onset of cardiovascular events. Hypertens. Res. Off. J. Jpn. Soc. Hypertens 39, 383-390.

Tei H, Okamura H, Shigeyoshi Y, Fukuhara C, Ozawa R, Hirose M, and Sakaki Y (1997). Circadian oscillation of a mammalian homologue of the Drosophila period gene. Nature 389, 512-516. [PubMed: 9333243]

Tognini P, Murakami M, Liu Y, Eckel-Mahan KL, Newman JC, Verdin E, Baldi P, and Sassone-Corsi P (2017). Distinct Circadian Signatures in Liver and Gut Clocks Revealed by Ketogenic Diet. Cell Metab 26, 523-538.e5. [PubMed: 28877456]

Tsai J-Y, Villegas-Montoya C, Boland BB, Blasier Z, Egbejimi O, Gonzalez R, Kueht M, McElfresh TA, Brewer RA, Chandler MP, et al. (2013). Influence of dark phase restricted high fat feeding on myocardial adaptation in mice. J. Mol. Cell. Cardiol 55, 147-155. [PubMed: 23032157]

Tso CF, Simon T, Greenlaw AC, Puri T, Mieda M, and Herzog ED (2017). Astrocytes Regulate Daily Rhythms in the Suprachiasmatic Nucleus and Behavior. Curr. Biol. CB 27, 1055-1061. [PubMed: 28343966]

Tsuneki H, Murata S, Anzawa Y, Soeda Y, Tokai E, Wada T, Kimura I, Yanagisawa M, Sakurai T, and Sasaoka T (2008). Age-related insulin resistance in hypothalamus and peripheral tissues of orexin knockout mice. Diabetologia 51, 657-667. [PubMed: 18256806]

Tsuneki H, Tokai E, Nakamura Y, Takahashi K, Fujita M, Asaoka T, Kon K, Anzawa Y, Wada T, Takasaki I, et al. (2015). Hypothalamic orexin prevents hepatic insulin resistance via daily bidirectional regulation of autonomic nervous system in mice. Diabetes 64, 459-470. [PubMed: 25249578]

Tsuneki H, Sasaoka T, and Sakurai T (2016). Sleep Control, GPCRs, and Glucose Metabolism. Trends Endocrinol. Metab. TEM 27, 633-642. [PubMed: 27461005]

Tsuzaki K, Kotani K, Sano Y, Fujiwara S, Takahashi K, and Sakane N (2010). The association of the Clock 3111 T/C SNP with lipids and lipoproteins including small dense low-density lipoprotein: results from the Mima study. BMC Med. Genet 11, 150. [PubMed: 20961464]

Ueta CB, Fernandes GW, Capelo LP, Fonseca TL, Maculan FD, Gouveia CHA, Brum PC, Christoffolete MA, Aoki MS, Lancellotti CL, et al. (2012). $\beta$ (1) Adrenergic receptor is key to cold- and diet-induced thermogenesis in mice. J. Endocrinol 214, 359-365. [PubMed: 22728333] 
Um JH, Yang S, Yamazaki S, Kang H, Viollet B, Foretz M, and Chung JH (2007). Activation of 5'AMP-activated kinase with diabetes drug metformin induces casein kinase Iepsilon (CKIepsilon)-dependent degradation of clock protein mPer2. J. Biol. Chem 282, 20794-20798. [PubMed: 17525164]

Van Cauter E, Désir D, Decoster C, Féry F, and Balasse EO (1989). Nocturnal decrease in glucose tolerance during constant glucose infusion. J. Clin. Endocrinol. Metab 69, 604-611. [PubMed: 2668321]

Vitaterna MH, King DP, Chang AM, Kornhauser JM, Lowrey PL, McDonald JD, Dove WF, Pinto LH, Turek FW, and Takahashi JS (1994). Mutagenesis and mapping of a mouse gene, Clock, essential for circadian behavior. Science 264, 719-725. [PubMed: 8171325]

Vrang N, Larsen PJ, and Mikkelsen JD (1995). Direct projection from the suprachiasmatic nucleus to hypophysiotrophic corticotropin-releasing factor immunoreactive cells in the paraventricular nucleus of the hypothalamus demonstrated by means of Phaseolus vulgaris-leucoagglutinin tract tracing. Brain Res 684, 61-69. [PubMed: 7583205]

Welsh DK, Takahashi JS, and Kay SA (2010). Suprachiasmatic nucleus: cell autonomy and network properties. Annu. Rev. Physiol 72, 551-577. [PubMed: 20148688]

Woon PY, Kaisaki PJ, Bragança J, Bihoreau M-T, Levy JC, Farrall M, and Gauguier D (2007). Aryl hydrocarbon receptor nuclear translocator-like (BMAL1) is associated with susceptibility to hypertension and type 2 diabetes. Proc. Natl. Acad. Sci. U. S. A 104, 14412-14417. [PubMed: 17728404]

Yasumoto Y, Hashimoto C, Nakao R, Yamazaki H, Hiroyama H, Nemoto T, Yamamoto S, Sakurai M, Oike H, Wada N, et al. (2016). Short-term feeding at the wrong time is sufficient to desynchronize peripheral clocks and induce obesity with hyperphagia, physical inactivity and metabolic disorders in mice. Metabolism 65, 714-727. [PubMed: 27085778]

Yi C-X, Serlie MJ, Ackermans MT, Foppen E, Buijs RM, Sauerwein HP, Fliers E, and Kalsbeek A (2009). A major role for perifornical orexin neurons in the control of glucose metabolism in rats. Diabetes 58, 1998-2005. [PubMed: 19592616]

Yi C-X, la Fleur SE, Fliers E, and Kalsbeek A (2010). The role of the autonomic nervous liver innervation in the control of energy metabolism. Biochim. Biophys. Acta 1802, 416-431. [PubMed: 20060897]

Yin L, and Lazar MA (2005). The orphan nuclear receptor Rev-erbalpha recruits the N-CoR/histone deacetylase 3 corepressor to regulate the circadian Bmal1 gene. Mol. Endocrinol. Baltim. Md 19, 1452-1459.

Zhang W, and Bi S (2015). Hypothalamic Regulation of Brown Adipose Tissue Thermogenesis and Energy Homeostasis. Front. Endocrinol 6, 136.

Zhao X, Hirota T, Han X, Cho H, Chong L-W, Lamia K, Liu S, Atkins AR, Banayo E, Liddle C, et al. (2016). Circadian Amplitude Regulation via FBXW7-Targeted REV-ERBa Degradation. Cell 165, 1644-1657. [PubMed: 27238018] 


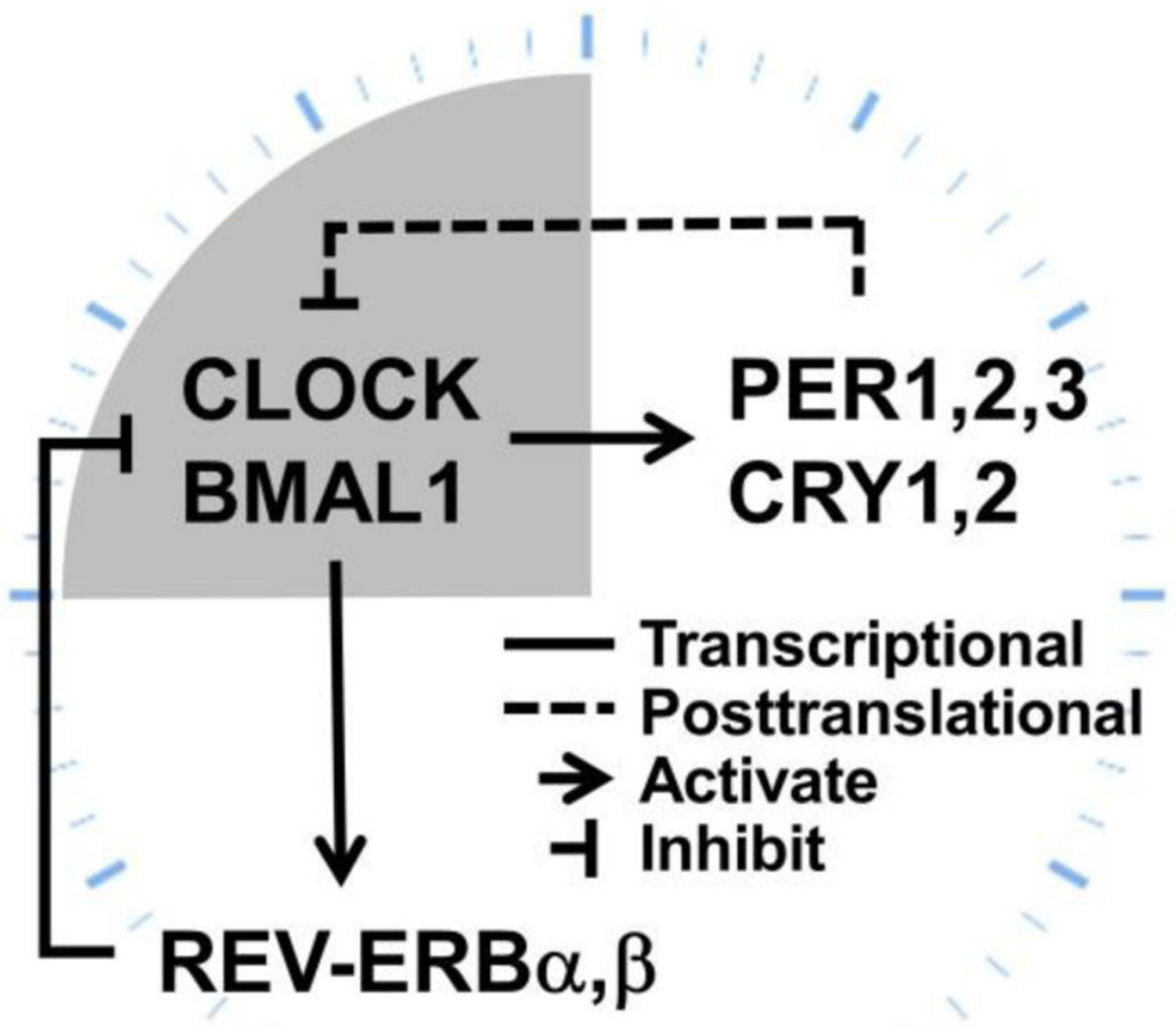

Figure 1.

The molecular circadian clock machinery. 


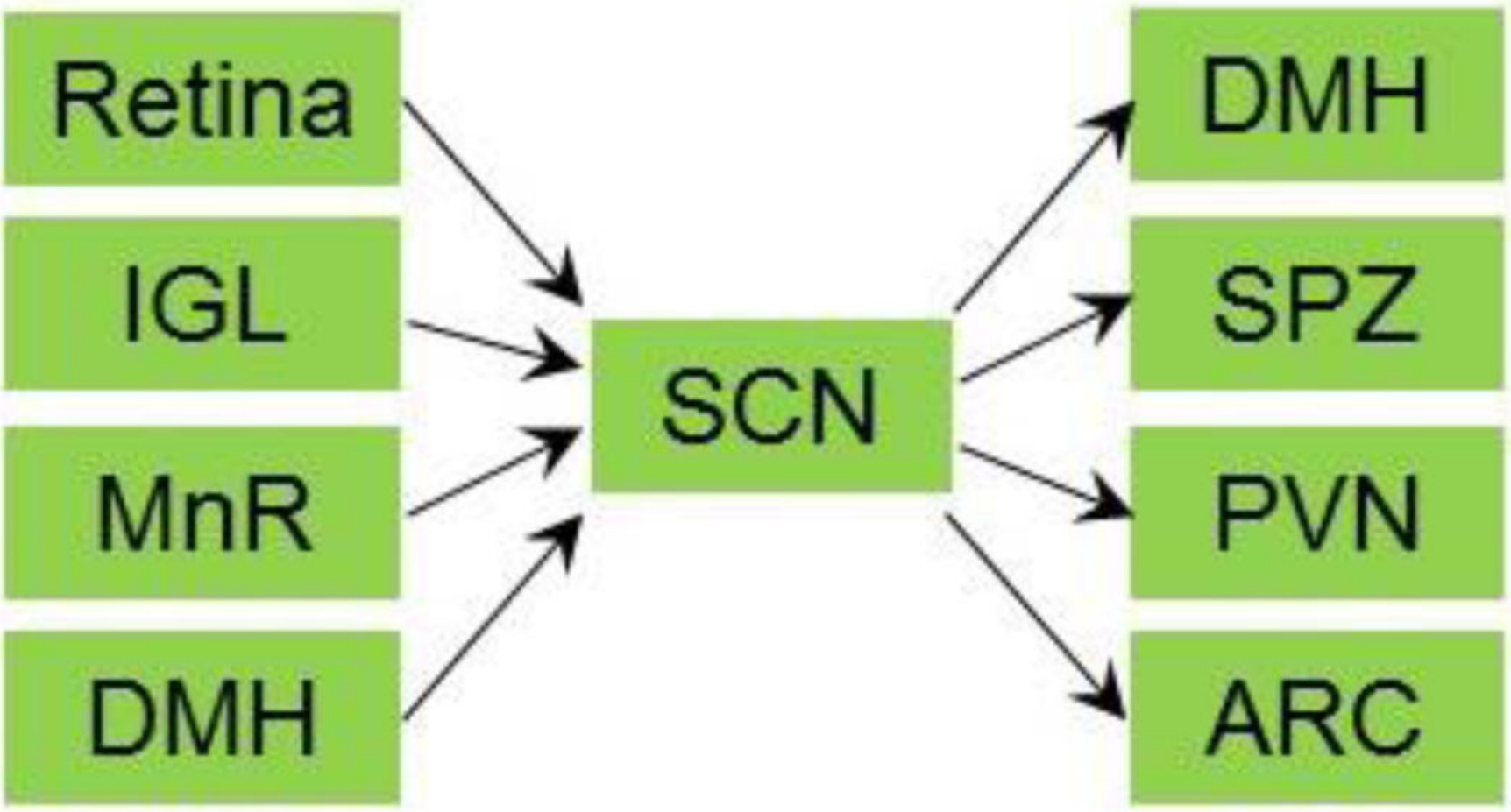

Figure 2. Major inputs and outputs of the SCN.

The suprachiasmatic nucleus (SCN) receives projections from retina, the thalamic intergeniculate leaflet (IGL), the median raphe (MnR), and the dorsomedial hypothalamic nucleus (DMH). The SCN projects to the DMH, the lateral subparaventricular zone (SPZ), the paraventricular nucleus (PVN), and arcuate nucleus (ARC). 
Table 1.

Genetic mouse models of adrenergic receptors (AR).

KO, knockout; DKO, double knockout; TKO, triple knockout; OE, overexpression.

\begin{tabular}{|c|c|c|}
\hline Model & Metabolic phenotypes compared to control wild-type (WT) & Reference \\
\hline a1A-AR KO & Lowered glucose uptake and GLUT translocation in the adult heart & (Shi et al., 2016a) \\
\hline a1A-AR OE & $\begin{array}{l}\text { Increased glucose uptake, increased GLUT1 and GLUT4 membrane translocation in } \\
\text { the adult heart }\end{array}$ & (Shi et al., 2016a) \\
\hline a1B-AR KO & $\begin{array}{l}\text { Higher blood glucose and insulin levels during the transition from fed to fasting, higher } \\
\text { leptin levels in the fed state, insulin resistance with impaired suppression of EGP, } \\
\text { higher susceptibility to diet-induced obesity and glucose intolerance }\end{array}$ & (Burcelin et al., 2004) \\
\hline a $2 \mathrm{~A}-\mathrm{AR} \mathrm{KO}$ & $\begin{array}{l}\text { Lower basal glucose levels, abolished effects of dexmedetomidine and atipamezole on } \\
\text { blood glucose or insulin levels }\end{array}$ & $\begin{array}{l}\text { (Fagerholm et al., } \\
\text { 2004) }\end{array}$ \\
\hline a $2 \mathrm{~A}-\mathrm{AR} \mathrm{KO}$ & Hyperinsulinaemia, lower blood glucose levels, improved glucose tolerance & (Savontaus et al., 2008) \\
\hline a 2C-AR KO & $\begin{array}{l}\text { Impaired glucose tolerance that was reversed by pretreatment with propranolol, higher } \\
\text { adrenaline secretion, unaltered insulin secretion }\end{array}$ & (Ruohonen et al., 2012) \\
\hline a $2 \mathrm{~A} / \mathrm{a} 2 \mathrm{C}-\mathrm{AR} \mathrm{DKO}$ & $\begin{array}{l}\text { Similar glucose and insulin phenotype as knock-out a }(2 \mathrm{~A})-\mathrm{AR} \text { alone, but more } \\
\text { sensitive to the glucose-lowering effect of insulin than WT mice. }\end{array}$ & (Ruohonen et al., 2012) \\
\hline $\begin{array}{l}\text { a } 2 \mathrm{~A}, \mathrm{a} 2 \mathrm{~B}, \text { or } \mathrm{a} 2 \mathrm{C}- \\
\mathrm{AR} \mathrm{KO}\end{array}$ & $\begin{array}{l}\text { Ex vivo experiments demonstrating that a } 2 \mathrm{~A} \text { and a } 2 \mathrm{C} \text { mediate the inhibitory effects of } \\
\text { adrenaline on pancreatic insulin release }\end{array}$ & (Peterhoff et al., 2003) \\
\hline$\beta 1-\mathrm{AR}$ KO & $\begin{array}{l}\text { Hypothermia during cold exposure and reduced BAT thermal response to } \\
\text { norepinephrine; more susceptible to diet-induced obesity, hypercholesterolemia, } \\
\text { hypertriglyceridemia, glucose intolerance, hyperglycemia, and steatohepatitis; } \\
\text { defective diet-induced thermogenesis }\end{array}$ & (Ueta et al., 2012) \\
\hline$\beta 2-\mathrm{AR}$ KO & $\begin{array}{l}\text { Lower hepatic triglyceride content and body weight during aging, } \\
\text { lower glucose tolerance in young age and improved glucose tolerance in old age }\end{array}$ & (Shi et al., 2016b) \\
\hline$\beta 2-\mathrm{AR} \mathrm{KO}$ & $\begin{array}{l}\text { Fasting hyperinsulinemia; higher PEPCK (PCK1) gene expression in the liver; similar } \\
\text { glucose intolerance, body weight gain, and liver lipid content as WT on high fat diet }\end{array}$ & $\begin{array}{l}\text { (Fernandes et al., } \\
\text { 2014) }\end{array}$ \\
\hline$\beta 3-\mathrm{AR}$ KO & $\begin{array}{l}\text { Normal BAT thermogenesis, increased susceptibility to diet-induced obesity, elevated } \\
\text { inflammation, similar glucose tolerance as WT, ameliorated hypertriglyceridemia and } \\
\text { hypercholesterolemia on high fat diet }\end{array}$ & (Preite et al., 2016) \\
\hline $\begin{array}{l}\beta 1,2,3 \_A R \text { TKO (beta- } \\
\text { less mice) }\end{array}$ & $\begin{array}{l}\text { Increased fat mass, glucose intolerance, impaired glucose-induced insulin secretion, } \\
\text { higher liver PEPCK gene expression in the fed state, enhanced insulin sensitivity }\end{array}$ & (Asensio et al., 2005) \\
\hline
\end{tabular}

